\title{
DEPOPULATION PROCESSES IN EUROPEAN RURAL AREAS: A CASE STUDY OF CANTABRIA (SPAIN)
}

\author{
Carmen Delgado Viñas ${ }^{1}$
}

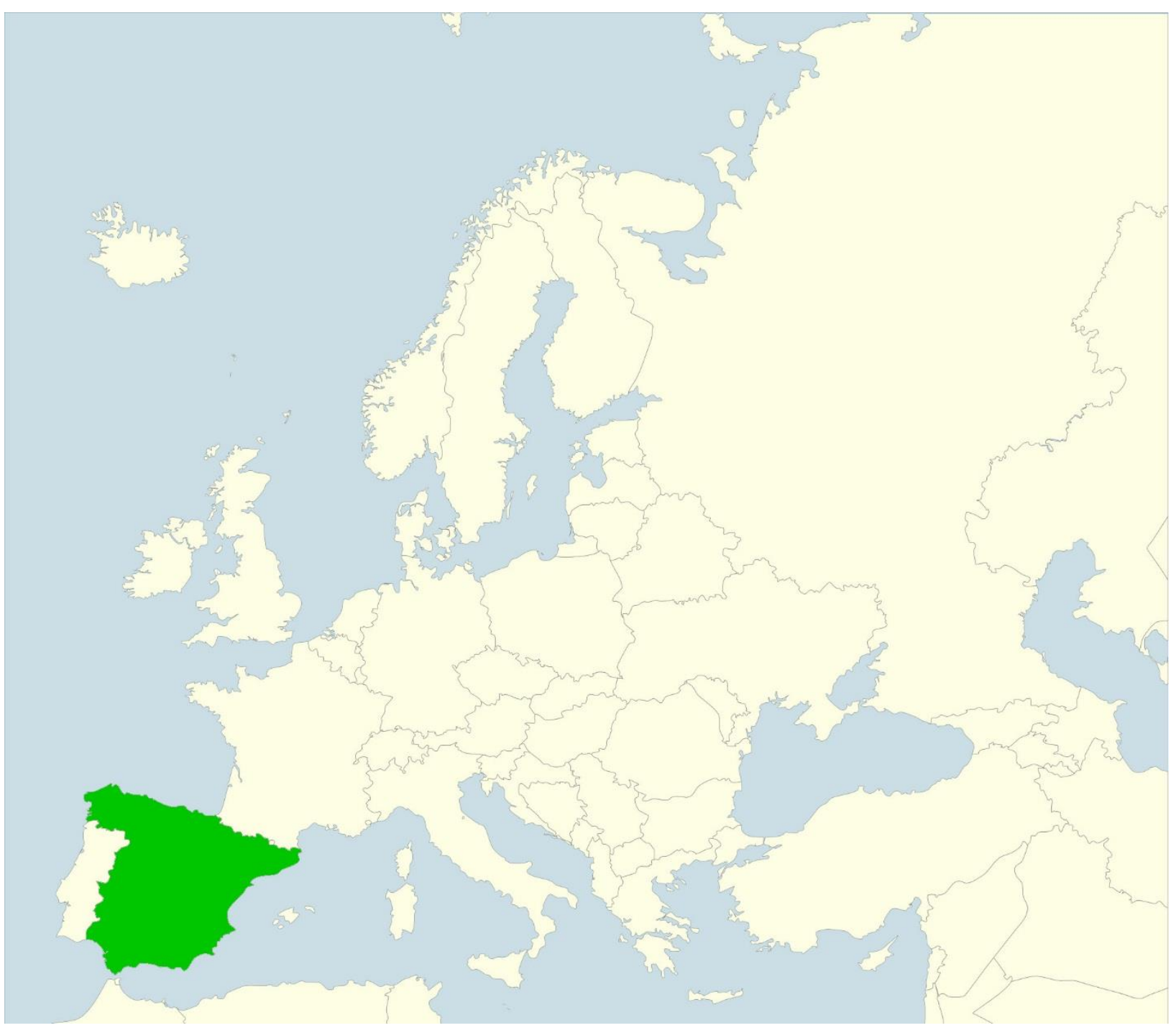

${ }^{1}$ PhD Carmen Delgado Viñas, Professor of Regional Geographical Analysis, Department of Geography, Urban and Regional Planning, University of Cantabria, Santander, Spain. ORCID: 0000-0002-9713-160X, e-mail: delgadoc@unican.es 
Abstract: Europe witnessed massive migration away from rural areas throughout the 20th century. Spain was no exception to the rule, albeit with differences in timing and pace, and the population in Cantabria constitutes a paradigmatic case. Here, the rural exodus began early - before the mid-20th century - in some mountainous districts, but reached a peak in the 1960s and continued throughout the following decades. Since the 1990s, population levels in rural municipalities have fallen at a slower rate, while the population of the region as a whole has increased slightly. Disturbingly, the rural population has continued to decline in the early $21^{\text {st }}$ century, in an overall context of almost zero population growth. The demographic trends analyzed here are not only different in time, but also in space. With the partial exception of regional capitals and their neighbouring communities, municipalities in mountain districts have witnessed such a substantial decline in their populations that they have experienced a genuine process of depopulation. This case does not explain the all-similar cases in rural Europe as a whole, but it can help in interpreting other comparable processes in different regions of southern Europe where depopulation reached its maximum in the second half of the 20th century and still continues today.

Key words: Depopulation, rural exodus, rural areas, mountain areas, Cantabria

Resumen: La población de los espacios rurales europeos ha sufrido un profundo proceso emigratorio a lo largo del siglo XX. La española no ha sido una excepción, aunque con diferencias de tiempo y ritmo, y la población de Cantabria constituye un caso paradigmático. Aquí el éxodo rural se inició precozmente en algunas comarcas, antes de mediada la centuria, pero alcanzó su etapa culminante a partir de los años sesenta y se prolongó durante las décadas siguientes. A partir de la última década del siglo XX la población de los municipios rurales ha seguido mermando a un ritmo menor en tanto que el conjunto poblacional de la región continuaba aumentando modestamente. El aspecto más preocupante es que los primeros años del siglo actual son testigos de la continuación de la pérdida de población rural en un contexto generalizado de estancamiento poblacional. La evolución demográfica analizada no es diferente sólo en el tiempo sino, también, en el espacio. Los municipios de las comarcas de montaña, con la excepción parcial de aquéllos en los que se encuentran situados los núcleos que funcionan como cabeceras comarcales y sus aledaños, han experimentado una disminución muy grande de su población hasta el punto de que en algunos puede hablarse sin exageración de un auténtico proceso de despoblación. El caso de Cantabria no explica todos los casos similares en la totalidad de la Europa rural, pero puede ayudar a interpretar otros procesos equiparables en diferentes regiones del sur de Europa donde la despoblación alcanzó su máximo en la segunda mitad del siglo XX y continúa en la actualidad.

Palabras clave: Despoblación, Éxodo rural, Espacio rural, Áreas de montaña, Cantabria

\section{Introduction: theoretical context}

Recent rural dynamics are primarily characterized by three interrelated trends: economic diversification, deagrarianisation and depopulation. The first two are common to all rural areas, whereas the third particularly affects the most disadvantaged areas. However, it is also true that deagrarianisation (Camarero Rioja, 2009, Collantes, 2007a, 2007b) and the simultaneous shift towards the service economy in present-day rural economies and societies has not led to the disappearance of the rural space but instead has given rise to new and multiple forms of 
rurality $^{2}$ (Sorokin \& Zimmerman, 1929; Hoggart, 1995, 2001a, 2001b; Ratier, 2002; Ballas, et al., 2004; Woods, 2005; Cloke, 1977, 2006; Waldorf, 2006; Jornad, 2009; Rieutort, 2012; Berdegué \& Proctor, 2014; Rauch, 2014; Goerlich, 2016).

The processes taking place in Cantabria are not unique or strictly local, but rather share many similarities with those occurring in other European regions and countries. Consequently, an analysis of rural areas in Cantabria can serve as a case study that in many respects can be extrapolated to other rural areas in Europe (Margaras, 2016) ${ }^{3}$.

A realistic distinction is made between rural areas that form part of urban and metropolitan areas, rural areas that are well connected to medium-sized urban centres and intermediate city networks, and remote rural areas that are poorly connected with any type of urban space. Although the criteria used to define and delimit rural areas in the European Union may differ according to the objectives pursued, in general they reflect a statistical and administrative approach based on the size of the local population, both in absolute (number of inhabitants ${ }^{4}$ ) and relative terms (population density ${ }^{5}$ ).

In line with the adoption of the basic principle of development guidelines, the OECD has established a rural typology that is indisputably complementary to those used previously (OECD, 1994, 2006, 2010): dynamic remote rural regions; lagging remote rural regions; dynamic intermediate regions; and lagging intermediate regions.

Similarly, a distinction is also often made between rural areas in the process of depopulation, with very weak economic activity that is highly dependent on agricultural production; intermediate rural areas in which agricultural activity continues to play an important role alongside other emerging economic activities; and rural areas presenting an extraordinary transformation of their economy and whereby agricultural activity has become relatively unimportant as urban activities and functions acquire greater protagonism. In fact, these comprise zones that fall between the countryside and the city where intensive rural urbanization or peri-urbanization processes are taking place (Bibby, 2004; Alario et al. 2018).

Specifically, regarding depopulated or sparsely populated areas, there is no agreement on the term used to designate them. Depending on each author's approach, or the issues they wish to stress, these areas are called sub-populated regions, remote rural areas, thinly populated, fragile or less favored areas, etc. In any case, they are always characterized by low population density and the fragility of their economy, both of which are related to significant geographical isolation and difficulties for territorial integration with other regions. The most widely accepted concept of depopulation refers to the process of chronic loss of population in a territory without any expectation of recovering or returning to the previous maximum population (García Valdivia, 2018; Johnson \& Lichter, 2019:4) 6 .

\footnotetext{
${ }^{2}$ It is no coincidence that the rural world was defined in the 1980 s as regions or areas where a diversity of activities are carried out (agriculture, handicrafts, small and medium-sized industries, trade, services, etc.), including natural and cultivated areas, villages, towns, small cities and regional capitals, together with "industrialised" rural areas in these regions (European Comission, 1988).

${ }^{3}$ Cantabria is a member of the Forum of Spanish Regions with Demographic Challenges (FreDD), a complementary organisation of the consortium of the Committee of the Regions of the European Union called Local and Regional Cooperation for Demographic Change, which includes the following European regions: Aragón, Galicia, Castile and León and Castile-La Mancha (Spain), northern and central Portugal, Basse-Normandie (France), MecklenburgVorpommern (Germany), Västra Götaland (Sweden), Dorset (United Kingdom), Aegean (Turkey) and Achterhoek (Netherlands).

${ }^{4}$ The Spanish National Statistics Institute (Spanish initials: INE) has defined rural areas as those with fewer than 2,000 inhabitants; semi-urban areas as those with between 2,001 and 10,000 inhabitants; and urban areas as those with more than 10,000 inhabitants.

5 The European Union has adopted the OECD classification based on population density: at the local level, rural municipalities are defined as those with a population density below 150 inhabitants $/ \mathrm{km}^{2}$; EUROSTAT has lowered this threshold to 100 inhabitants $/ \mathrm{km}^{2}$, a figure which is considered to more closely reflect the circumstances of rural areas in Europe (Eurostat, 2010).

${ }^{6}$ Population decline is defined as the combination of absolute decline in the population and a negative change of more than 2.5 percentage points in the share of the countries' total population. As some states are declining in absolute terms, this double criterion ensures that entire countries are not selected. The choice of the criterion was made in order to gain a representative sample of regions that would correspond to $+/-20 \%$ of the total number of regions.
} 
Chronic population decline or depopulation has become a familiar pattern of population change in many low-fertility countries in the developed world. (Münz 2006; Nikitina 2000). Rural areas have "emptied out" as urbanization has continued apace throughout much of Europe (MacDonald, 2000; Carrasco, 2012), United States of America (Wuthnow, 2018; Johnson \& Lichter, 2019) and in many East Asian countries (Matanle, 2011; Xingan, 2015).

The objective of this paper is not to debate on the causes of such substantial population dynamics, but it does seem appropriate to refer to the arguments of the most eminent authors.

Most of the research coincides in pointing out that the process of population loss in European rural areas is not the result of a specific crisis. It is due to a two-century-long structural situation that has been aggravated by certain episodes. From this perspective, depopulation may be seen as a specific case of a more general phenomenon, which was the rural exodus caused by modern economic growth.

Extensive literature exists on the phenomenon of rural-urban migration and rural depopulation in Europe and different theories abound, but they all have a common denominator: the causes of depopulation are not natural but political and economic. The generally accepted causal factors that explain depopulation processes include demographic regression, intense de-ruralization, deagrarization, poor transportation links, etc.

In relation to the theories describing changes in the economic system, some authors defend the idea of the disintegration of the traditional mountain economies that were based on agricultural activities. This took place with the penetration of the market economy with its logic of accumulation and re-production (Commins, 1978; Dunaway, 1996; Collantes, 2001b, 2004b). It therefore seems that integration in a different economic system and globalization produces an acceleration of depopulation processes.

These changes have stimulated and aggravated territorial polarization dynamics that have triggered especially intense effects in areas with less capacity to compete. Mountain areas have a less diversified economic base, more difficult accessibility, more orographic and climatic disadvantages for agrarian production, smallholder farms, etc. (Rieutort, 1997; Collantes, 2004a). Additional factors include deficiencies in equipment and services. It is therefore not so much of a problem of the internal decadence of traditional models; it is more a question of maladjustment to new global contexts and a lack of economic, social and territorial cohesion.

For a long time, there has been great concern over the economic and environmental problems produced by this process (Coleman, 2011; Smailes, 2002). Various studies suggest that low population levels and remote locations mean that the economies of sparsely populated and underpopulated regions tend to grow at rates far below the EU average or to stagnate altogether (Gáková, 2010). Low population density, the aging population, low birth rates and population loss due to emigration are the four main challenges rural areas face (FEMP, 2017a, 2017b). Article 174 of the Treaty on the Functioning of the European Union (TFEU) suggests that particular attention should be paid to 'regions which suffer from severe and permanent natural or demographic handicaps', such as the northernmost regions that have a very low population density and island and mountainous regions.

In the context of Western Europe, the industrialization, modern economic growth and urbanization that have taken place during the previous two centuries have been the drivers of rural depopulation processes, but the pace and intensity of this varies considerably from one country to another.

In some Western European countries, this took place mainly in the last third of the 19th century and the first half of the 20th century. This is the case, for example, in France (Merlin, 1965; Herbin, 1984; Estienne, 1989; Desbordes, 1991; Mathieu, 2000) and the United Kingdom (Saville, 1957; Lawton, 1973; Wrigley, 1986, 2001; Short, 2000). Since the end of the Second World War, and throughout the second half of the 20th century, the process has slowed down and, in recent decades, there has even been an opposite process of emigration from the city to the countryside, to the point that the functionality of some rural spaces has changed due to peri-urbanization and 
rural-urbanization processes (Berry, 1976; Bauer, G. \& Roux, 1976; Entrena, 2005, 2006, 2012; Berdegué, 2014).

The demographic stabilization of the rural spaces of these countries coincided with the beginning of the process in southern Europe. In Italy (Giusti, 1943; Mazzoleni \& Negri, 1981; Negri, 1993; Albera, 2000; Dadá, 2000), Spain (Collantes, 2005; Gómez Mendoza, 2016; del Molino, 2016) and Portugal (Castro, 1992; Pires, 2017), rural depopulation has become a dramatic problem. Following a similar dynamic, the process is currently taking place in the countries of Central and Eastern Europe, although the densities of rural population are still high in some of those that have later joined the European Union (Romania, Bulgaria,Croatia).

The depopulation of rural areas, especially mountainous regions, began in Spain in a generalized way in the 1950s, after the most difficult years of the Spanish post-civil war period (Collantes \& Pinilla, 2004, 2011). Most authors agree that differences in employment and salary opportunities were the main reasons for rural exodus, especially in the 1950-1975 period during which the only role attributed to the countryside was to provide food and labour to the cities. (Camarero Bullón, 2009). This exodus was very selective and it included primarily young people from rural areas that fed emigration (Camarero Rioja, 2009: 28).

The approximate half-century delay with respect to other European countries was more than compensated in the following two decades. In Spain, the process was much quicker, more intense and longer than in the other countries of Western Europe, including the Mediterranean ones (Ayuda \& Pinilla, 2000, 2002, 2007; García Sanz, 2003; Miranda, 2006; Pinilla, Ayuda \& Sáez, 2006; Gómez-Limón, 2007; López Trigal, 2009; Guirado \& Tulla, 2010; Senado de España, 2015; Bustos Alecha, 2016; Aparicio, 2016; López Fernández, 2016; Leco, 2016, 2017; Santos, 2016; Palacios, 2017; Pinilla \& Sáez, 2017; Rodríguez, 2017; Bustos Gisbert, 2018; Delgado, 2018; Pérez \& Leco, 2018; Pazo, 2018; Domínguez, 2019). In none of them did the cumulative depopulation of mountainous areas reach $1 \%$ annually during the second half of the 20th century, which was the case in Spain (Macarrón, 2011). The process was so intense that Spain has some of the most unpopulated rural areas in Europe, with less than 3 inhabitants per $\mathrm{km}^{2}$, although this is not one continuous territory but a large number of scattered areas. According to the Spanish Federation of Municipalities and Provinces (FEMP), more than 4,995 municipalities, out of a total of 8,125 , are at risk of mid- or long-term extinction because they currently have less than 1,000 inhabitants; 1,286 of them actually have less than 100 inhabitants (FEMP, 2017a, 2017b). This is not a problem of lack of population at the state level. It is more a question of the imbalance that exists in the distribution of the population, since over half of the Spanish territory, $53 \%$, is home to only $5 \%$ of the population.

There is also no unanimous agreement on the criteria and thresholds for defining and delimiting depopulation. The criterion applied by the European Commission is the population density threshold, $12.5 \mathrm{inh} / \mathrm{km} 2$, to identify regions at the NUT3 level that can be defined as "sparsely populated". Applying this indicator, $17.2 \%$ of the territory included in the ESPON program (European Observation Network for Territorial Development and Cohesion) corresponds to depopulated areas. In the guidelines on regional aid for the period 2014-2020 (2013 / C 209/01), sparsely populated areas are defined from the EUROSTAT population density data for 2010 as NUT2 regions with less than 8 inhabitants per $\mathrm{km}^{2}$ (ADE, 2012).

To some extent, these classification categories underlie the formulation of the Spanish Law on Sustainable Development in Rural Areas ${ }^{7}$. As its name suggests, the aim of this law is to promote development in rural areas, understood from a new territorial perspective (González, 2008) . Article 3 of this Act states, that rural municipalities are those with less than 5,000 inhabitants and a density of less than 100 inhabitants per square kilometer. Likewise, the rural area is defined as

\footnotetext{
7 Law 45/2007 of 13 December 2007, BOE 299, pp. 51339-51349.

${ }^{8}$ As explicitly stated in its Preamble I: "It is a law of territorial orientation, which implies that it will be applied taking into consideration land use planning criteria and directives. The law contemplates rural areas differentiated according to an established typology, defines priority rural areas and provides for the establishment of a plan by rural area. The actions and measures envisaged in the law are multi-sectoral and environmental. These reflect the new reality of an ever more economically diversified rural environment and recognise an important multifunctionality for society as a whole" (the emphasis is mine).
} 
the territory formed by the aggregation of municipalities or smaller local entities that have a population of less than 30,000 inhabitants and a population density of less than 100 inhabitants per $\mathrm{km}^{2}$.

Given the diversity of criteria and geographical scales, it is difficult to quantify the demographic dimensions of depopulation in European rural areas. However, an approximation can be made.

Recent reports by the European Parliament, which uses the Local Administrative Units level (LAU2) as its base, estimate that 3.2 million people lived in sparsely populated areas. Most of these are found mainly in northern Europe, but some smaller areas with low population potential were also identified in the Baltic States, Corsica, some Greek islands and the Eastern European countries (Thorez, 1987; Vartiainen, 1989; Pasakarnis, 2013; Pokos, 2015).

Some of the authors who have done extensive research on the problem of depopulation in the Spanish mountainous areas state that depopulation was less intense in the mountains in the north of the peninsula. I think that this is questionable, at least in the interpretation of the data used in the present study as regards the Cantabrian Mountains (Delgado, 2008; 2013).

The fundamental cause of this error is the irregular distribution of the population in the Cantabrian territory, which is concentrated in a few costal and pre-coastal municipalities. Something similar has also taken place in Galicia (Pazo and Moragón, 2018). Statistics aside, the geographical reality is that half of the Cantabrian territory, especially the mountain areas, shows conditions similar to the southern mountainous area of the adjoining regions, particularly Castile and Leon. This means that, in the entire EU, the population density of some mountainous areas of Cantabria can only be matched by the Scottish Highlands or the northern regions of Sweden or Norway.

Many researches consider that the established statistical criteria and the scales of analysis generally proposed (NUT3 or NUT2) are inadequate. They believe that local level municipal scale data, LAU2, is needed to measure the territorial processes. This is mainly because the regional indicators, although to a lesser extent than the indicators at the state level, mask the true reality of depopulation processes. At present, the dynamics of the rural population present extremely unequal patterns at the sub-state and even subregional scale, and this phenomenon affects in particular the remote rural areas.

In relation to the above, the main objectives of the research on which this article is based is to understand the genesis, dynamics and contemporary patterns of rural depopulation processes in Spain, using Cantabria as a base. Although this research basically refers to rural areas, it has been considered necessary to sometimes provide data for urban and semi-urban areas in order to make a comparative analysis and highlight the contrasts in the dynamics of different types of geographical areas.

In agreement with other proven theories, my research was proposed to demonstrate that the current depopulation is the continuation of processes rooted in the past. Future initiatives looking at causes and solutions must make sure they consider this. The main goal of the study can be broken down into the following complementary objectives:

- To investigate the dynamics and the past and current patterns of population decline in rural areas of Cantabria.

- To contrast the intensity and timing of the processes occurring in rural areas of Cantabria with those in Europe and Spain.

- To provide us with a clear view regarding the future of these mountainous areas. These depopulation processes, which continue at the beginning of the 21st century, are an exceptional situation in the Western European context and are difficult to reverse.

- To understand the reality of the process at the subregional and local levels in order to verify that depopulation, although generally linked to rural spaces, does not affect them all or in the same way.

- To expose and highlight contrasts and differences between peri-urban and rural-urban areas and remote areas, essentially mountainous areas with poorer productive conditions and accessibility. 


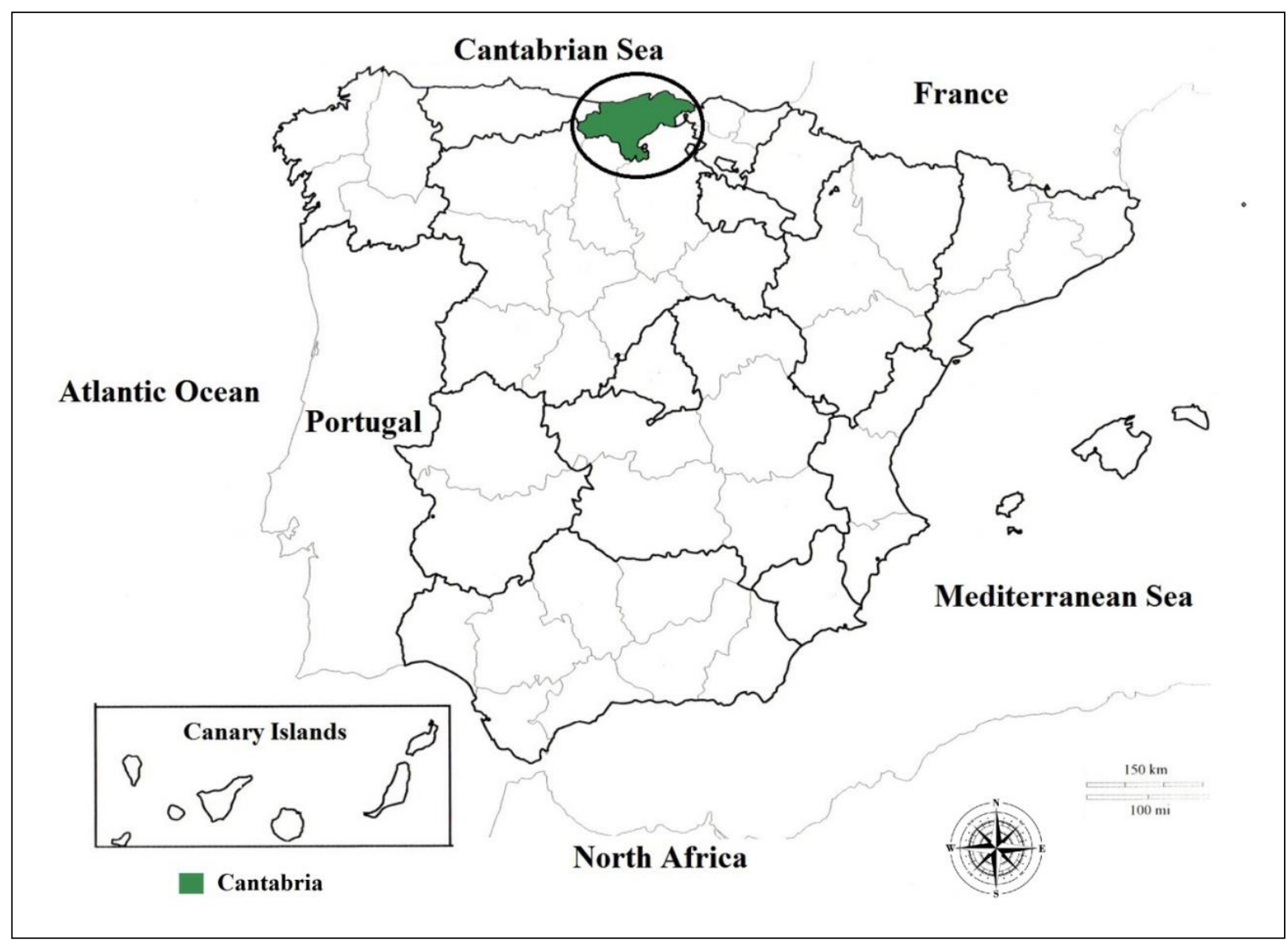

Fig 1. The Autonomous Community of Cantabria in Spain. Source: the author

\section{Methodology}

The present research sprang from a previous "Baseline study to identify the areas of application in Cantabria of the Law on Sustainable Development in Rural Areas" (Delgado, 2006, 2007, 2009) commissioned by the Department of Agriculture of the Government of Cantabria. The data has been updated and the results have been interpreted using the theoretical framework from studies on rural depopulation processes at various levels. An analysis has been conducted on the dynamics experienced by the rural spaces of Cantabria up to the present day as a starting point to establish the conditions required for the sustainable development of rural areas.

To analyze recent dynamics in rural areas in Cantabria, a series of basic indicators, coinciding with those commonly applied, have been used to characterize and subsequently delimit rural areas. In order of importance, the main indicators employed were:

- Intensity of occupation and land use by the population. This entailed a brief study of recent trends in population levels, population density and population distribution patterns in terms of levels of population dispersion and/or concentration.

- The structural features of the population, especially age and sex, levels of ageing, natural population movements, and the birth and death rates.

- Occupational structure of the population as regards its sectoral distribution, paying particular attention to the relative importance of agricultural and forestry activities in relation to direct exploitation of territorial resources.

- Accessibility measured as the distance in travel time to regional urban centres that provide a sufficient quantity and quality of services and facilities. These centres were defined as urban agglomerations with more than 30,000 inhabitants, which in Cantabria were the regional and sub-regional centres (Santander, Torrelavega and Castro Urdiales). 
- The main characteristics of the terrain in Cantabria, paying particular attention to aspects, such as the orography and levels of flatness and/or slopes, that create an added disadvantage for the residents in terms of accessibility and opportunities for engaging in agricultural activities,.

- The main characteristics of the terrain in Cantabria, paying particular attention to aspects, such as the orography and levels of flatness and slopes, that create an added disadvantage for the residents in terms of accessibility and opportunities for engaging in agricultural activities.

- Distribution of per capita gross available income as an indicator that synthesises the above conditions.

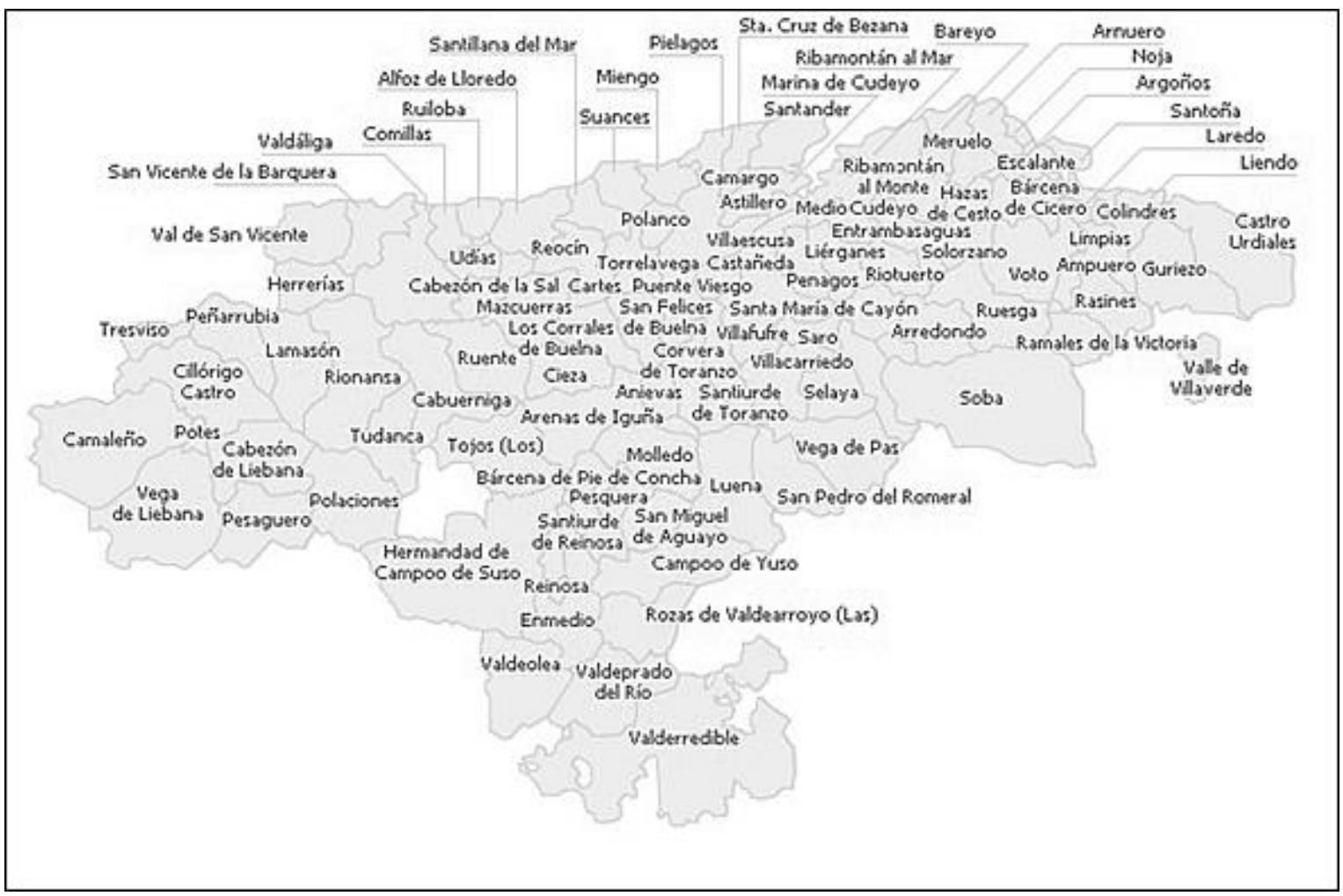

Fig 2. Municipalities of the Autonomous Community of Cantabria. Source: Government of Cantabria. General Directorate of Local Administration.

\section{Results: rural dynamics in early $21^{\text {st }}$ century Cantabria}

\subsection{Definition and delimitation of the rural areas of Cantabria}

After applying the indicators proposed to demarcate the areas for the application of the Law on Sustainable Development in Rural Areas, rural areas in Cantabria were defined as territorial areas containing municipalities with fewer than 30,000 inhabitants and a density below 100 inhabitants $/ \mathrm{km}^{2}$. Seventy-one of the 102 municipalities in Cantabria (69.6\%) met both these conditions in 2008, accounting for a total area of $4,385.96 \mathrm{~km}^{2}$ (83.5\% of the region) and 92,533 inhabitants (15.9\% of the total population in the region) (Fig. 3; Table 1). Applying the same demarcation criteria to the present, the two aforementioned conditions now account for -seven municipalities $(65.68 \%$ of the total) with 79,959 inhabitants $(13.73 \%$ of the regional population) and occupying $4,276 \mathrm{~km} 2\left(80.28 \%\right.$ of the total area of Cantabria) ${ }^{9}$.

These imbalances between the percentages of land area and population depict at first glance the low population in such municipalities and the vast difference in population density.

9 The municipalities of Bárcena de Cicero, Castañeda, Entrambasaguas and Meruelo have ceased to fulfill these conditions and they have become part of the category of peri-urban municipalities. 
Tab 1. Main characteristics of Cantabrian rural areas (2016). Source: compiled by the author based on INE data, population censuses and municipal residents' registers

\begin{tabular}{|l|r|r|}
\hline \multicolumn{1}{|c|}{ Indicators } & Total Cantabria & Rural areas of Cantabria \\
\hline Number of municipalities & 102 & $67(65.7 \%)$ \\
\hline Population (inhabitants) & 582,206 & $79,959(13.7 \%)$ \\
\hline Area $\left(\mathrm{km}^{2}\right)$ & 5,326 & $4,276(80.3 \%)$ \\
\hline Density (inhabitants/km²) & 109.3 & 26.7 \\
\hline Agricultural jobs (\%) & 3.3 & 20.6 \\
\hline $\begin{array}{l}\text { Gross disposable income } \\
\text { per capita 2015 (€) }\end{array}$ & 14,190 & 10,059 \\
\hline $\begin{array}{l}\text { Annual change in population } \\
\text { 1996-2016 (\%) }\end{array}$ & 0.5 & -0.2 \\
\hline People over 65 years (\%) & 20.7 & 27.7 \\
\hline Dispersed population (\%) & 17.83 & 62.05 \\
\hline
\end{tabular}

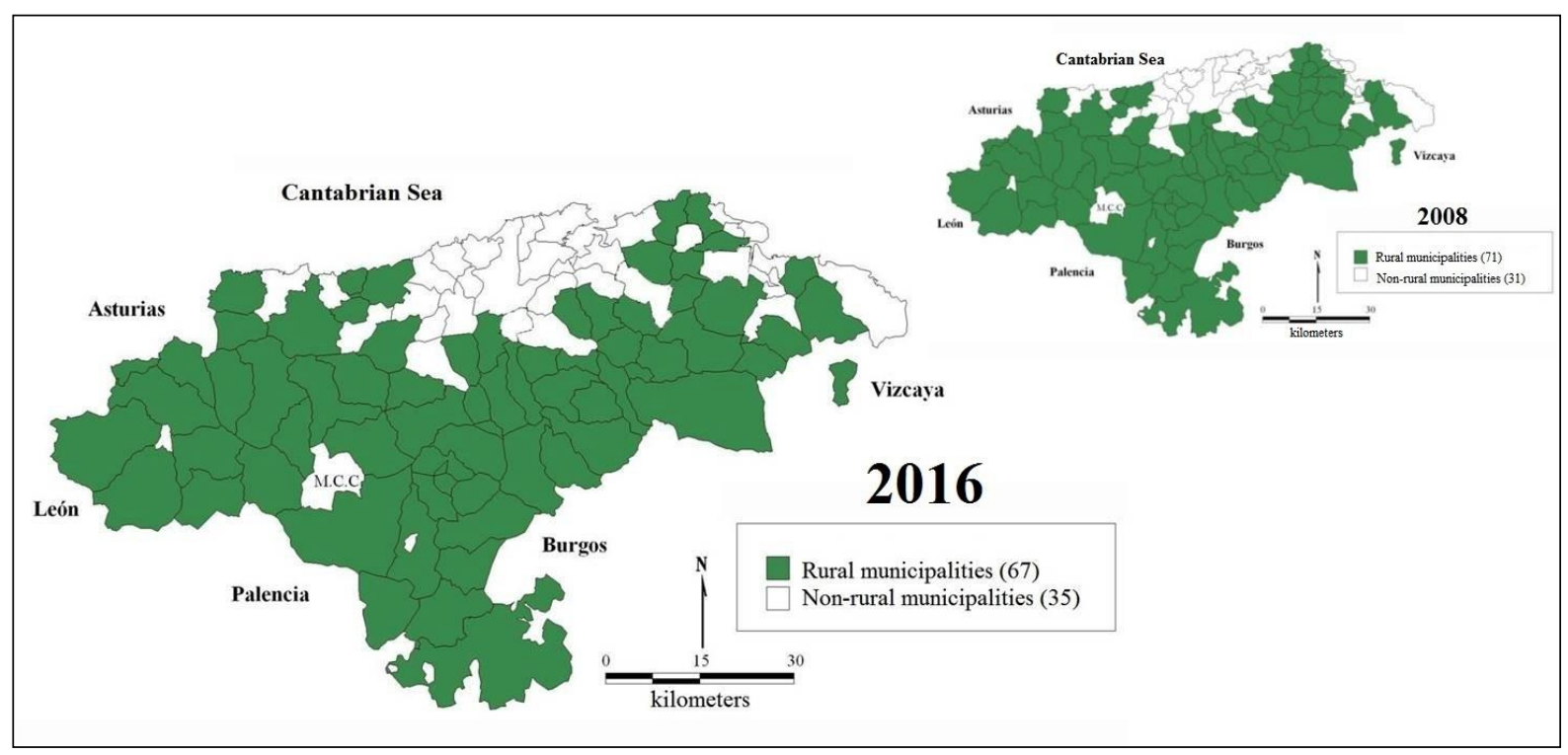

Fig 3. Distribution and location of Cantabrian rural municipalities (2008 and 2016). Source: by the author based on INE data

\subsection{The territorial reality of Cantabria at the beginning of the 21st century}

The orography in Cantabria honours the region's historic name of La Montaña (The Mountain). The rugged relief is clearly evidenced by the indicator that measures the percentage of slopes in the territory: slopes over $30 \%$ account for $32.74 \%$ of the region, a high number which again masks very different situations.

On a regional scale, there are two clearly different situations. On the one hand, there are areas with lower slopes, corresponding to municipalities along the northern coast, and on the other, there are areas with a predominance of high-altitude flat land, corresponding to the southern end of the Campoo district in the central sector dividing the Cantabrian mountain range. In both cases, slopes account for less than $25 \%$ (and sometimes less than 15\%) of the terrain in most of the municipalities. It is between these two areas that the majority of municipalities in Cantabria with slopes above $25 \%$ are located. These are the inland valleys, the middle and upper stretches of Cantabria's rivers and the southern mountains. The highest values correspond to districts in 
the western Cantabrian mountain range (Liébana, Cabuérniga and Tudanca) and the eastern Cantabrian mountain range (the Montes de Pas in the upper Pas, Miera and Asón river valleys).

Clearly, this rugged orography (Fig. 4) constitutes a natural disadvantage since it hinders economic activity and mobility and represents an obstacle to regional development that must be overcome through compensatory measures. Hence, rural mountain areas in Cantabria are at a clear disadvantage because they are less accessible and it is more difficult to use the land for agricultural production.

Although road transport and communication infrastructures have fortunately improved considerably in recent years, marked territorial differences remain in terms of connectivity and accessibility. These differences were measured according to the distance in travel time from the main centre in each municipality to the nearest city with more than 30,000 inhabitants, a population size that ensures the availability of a sufficiently wide range of services ${ }^{10}$. Furthermore, all these urban areas are located close to the north coast. Consequently, the southern half in the region, which is the most mountainous area with the greatest natural barriers to mobility, is precisely the one furthest from these centres. A high number of municipalities have quite rapid access to the nearest city: less than 30 minutes in 28 cases. In contrast to these "fortunate" cases, however, the inhabitants of another 16 rural municipalities have to travel more than 45 minutes to reach a regional or sub-regional service centre, placing them at an evident disadvantage in terms of purchasing goods and using anything beyond basic services.

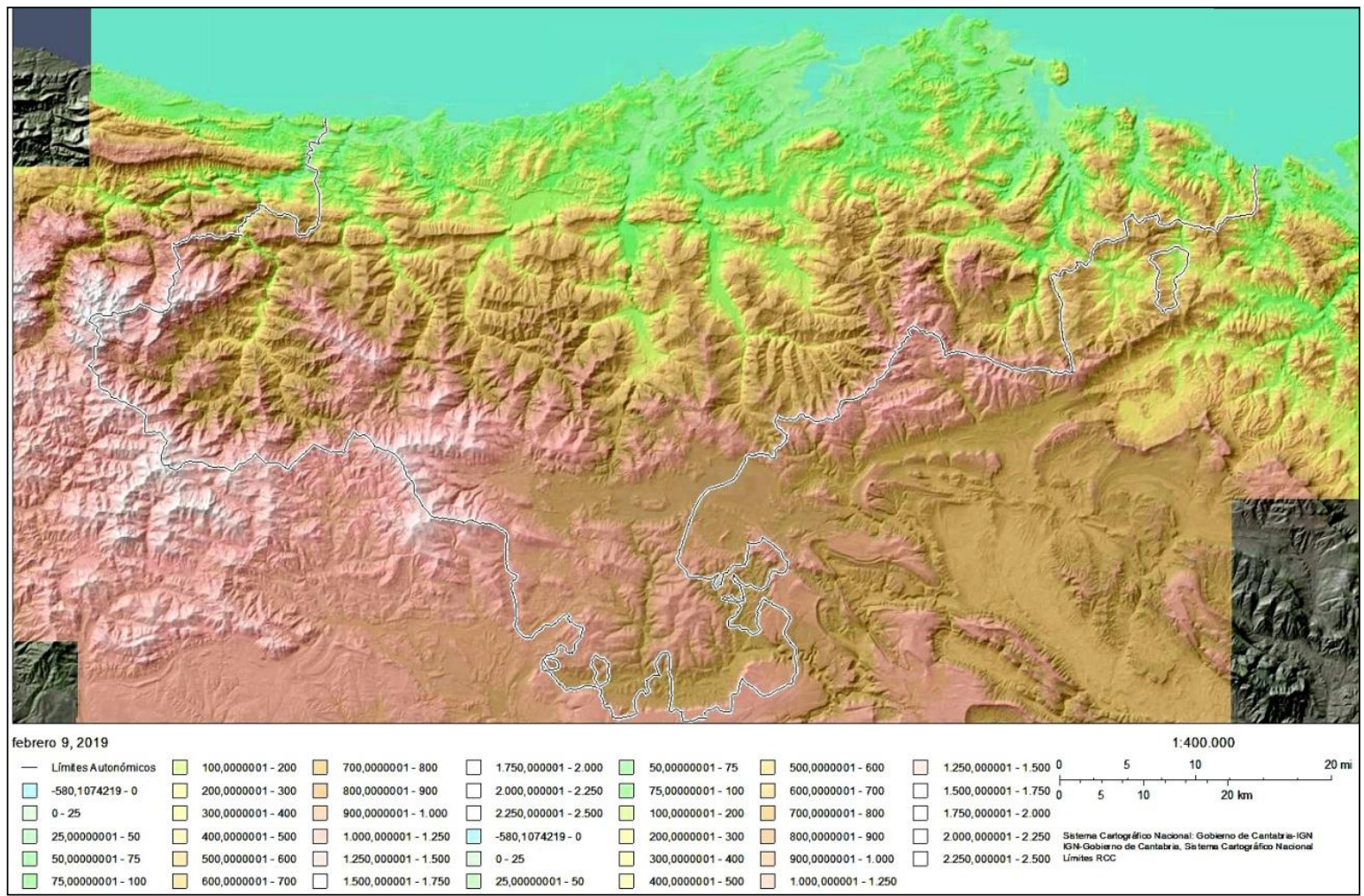

Fig 4. Orographic characteristics of the Cantabrian relief (altitude). Source: by the author based on cartography of the Government of Cantabria, Directorate General of Territorial Planning

Due to the above, it must be noted that the present population distribution in Cantabria is extremely unbalanced, as is immediately evidenced when the municipalities are ranked by population size (Fig. 5).

\footnotetext{
10 Only four municipalities have a population of more than 30,000 inhabitants (Santander, Torrelavega, Camargo and Castro Urdiales), and these could in fact be considered only three urban agglomerations since Camargo is a peri-urban municipality adjoining Santander, practically a suburb of the regional capital.
} 
Only five municipalities out of 102 have more than 20,000 inhabitants (Santander, Torrelavega, Piélagos, Camargo and Castro Urdiales), and they are all located in the northern coastal area of Cantabria. In 2016, these five municipalities accounted for $53.68 \%$ of the total population.

With regard to the rest of the municipalities, only seven exceed the threshold of 10,000 inhabitants, which would define them as urban according to the Spanish statistical criterion; these municipalities only accounted for $11.05 \%$.

What could be considered semi-urban municipalities, between 2,000 and 10,000 inhabitants, accounted for $26.77 \%$ of the population. In most cases, they are part of the peri-urban areas of Santander and Torrelavega or the small agglomeration that is forming at the mouth of the river Asón, known as the "Ría de Treto". Conversely, the 56 statistically rural municipalities, with fewer than 2,000 inhabitants, were home to only $8.48 \%$ of Cantabria's total population.

The imbalance in population distribution is even greater at the local level because another fundamental characteristic is the high level of dispersion.

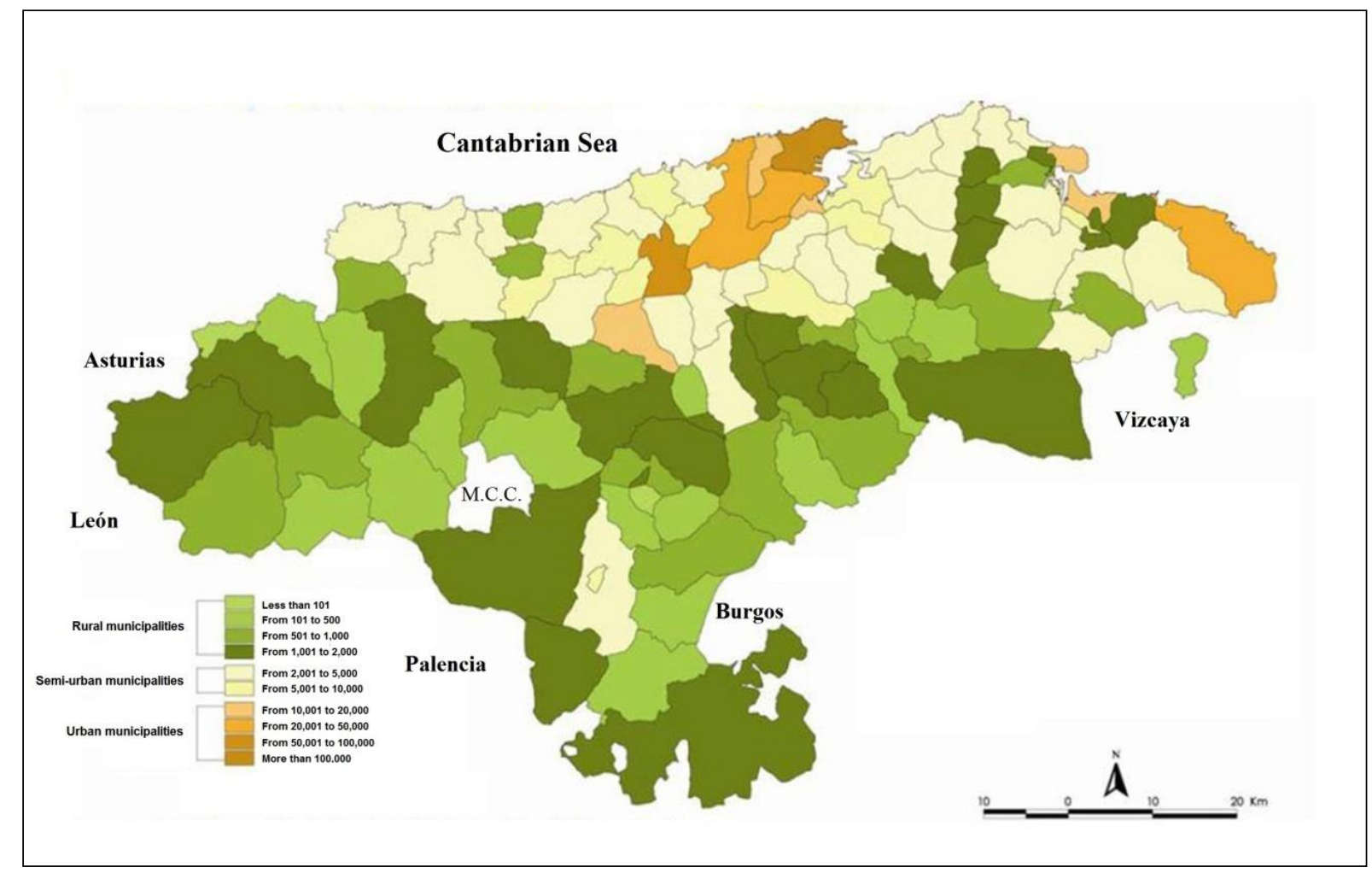

Fig 5. Distribution of Cantabrian municipalities according to population size and urban-rural classification (2016). Source: by the author based on Statistical Institute of Cantabria (ICANE)

The traditional settlement pattern is characterized by the existence of a multitude of very small villages, a model that, at present, is absolutely dysfunctional. Sometimes, a somewhat larger community serves as a small, local centre providing basic services. These are not purely dispersed settlements because the houses are gathered in small agglomerations, although without being closely connected, endowing them with the appearance of a community. However, their diminutive size and their distribution interspersed with unconstructed spaces suggest the idea of dispersion. The problem is further exacerbated in municipalities with fewer inhabitants, where dispersion is greater.

Recently, the construction of numerous second and holiday home housing developments has heightened this dispersion by adding new, small settlements to existing ones, particularly along the coast. The same effect is exerted by the construction of isolated second homes, magnifying the previously mentioned interspersion in coastal areas and, in this case also, in municipalities in southern mountain districts, where housing developments with terraced or detached houses remain rare. 
Thus, in municipalities with fewer than 2,000 inhabitants, more than $60 \%$ of the population is dispersed, while in "semi-urban" municipalities with between 2,000 and 5,000 inhabitants, slightly more than half of the population is dispersed. In "pre-urban" municipalities with between 5,000 and 10,000 inhabitants, the dispersed population accounts for just over a third of the total.

The present situation is primarily the result of population trends over the $20^{\text {th }}$ century, particularly in the second half.

\subsection{The prolonged and discriminated process of rural depopulation in Cantabria}

Throughout the $20^{\text {th }}$ century and into the early $21^{\text {st }}$ century, Cantabria witnessed moderate population growth. Its population has doubled, increasing from 276,003 inhabitants in 1900 to 582,206 registered residents in 2016 , representing an increase of $110.94 \%$ (0.95\% per year), which is nevertheless much lower than that for Spain as a whole in the same period $(150.06 \%$ and $1.29 \%$ per year respectively). However, this population growth has been uneven, both over time and in its distribution throughout Cantabria. From a spatial point of view, there have been marked imbalances in demographic trends in the phases of expansion and stagnation alike.

In the first half of the $20^{\text {th }}$ century, in a context of greater regional growth, municipal contrasts evidence the uneven impact of the onset of the process of economic and demographic modernisation (Fig. 6). Most municipalities in the western mountainous regions (Liébana and Cabuérniga), many in the central (Campoo) and in the eastern end of the region (Montes de Pas) experienced significant population losses, although the decline was far less marked than the population haemorrhage that occurred in subsequent decades.

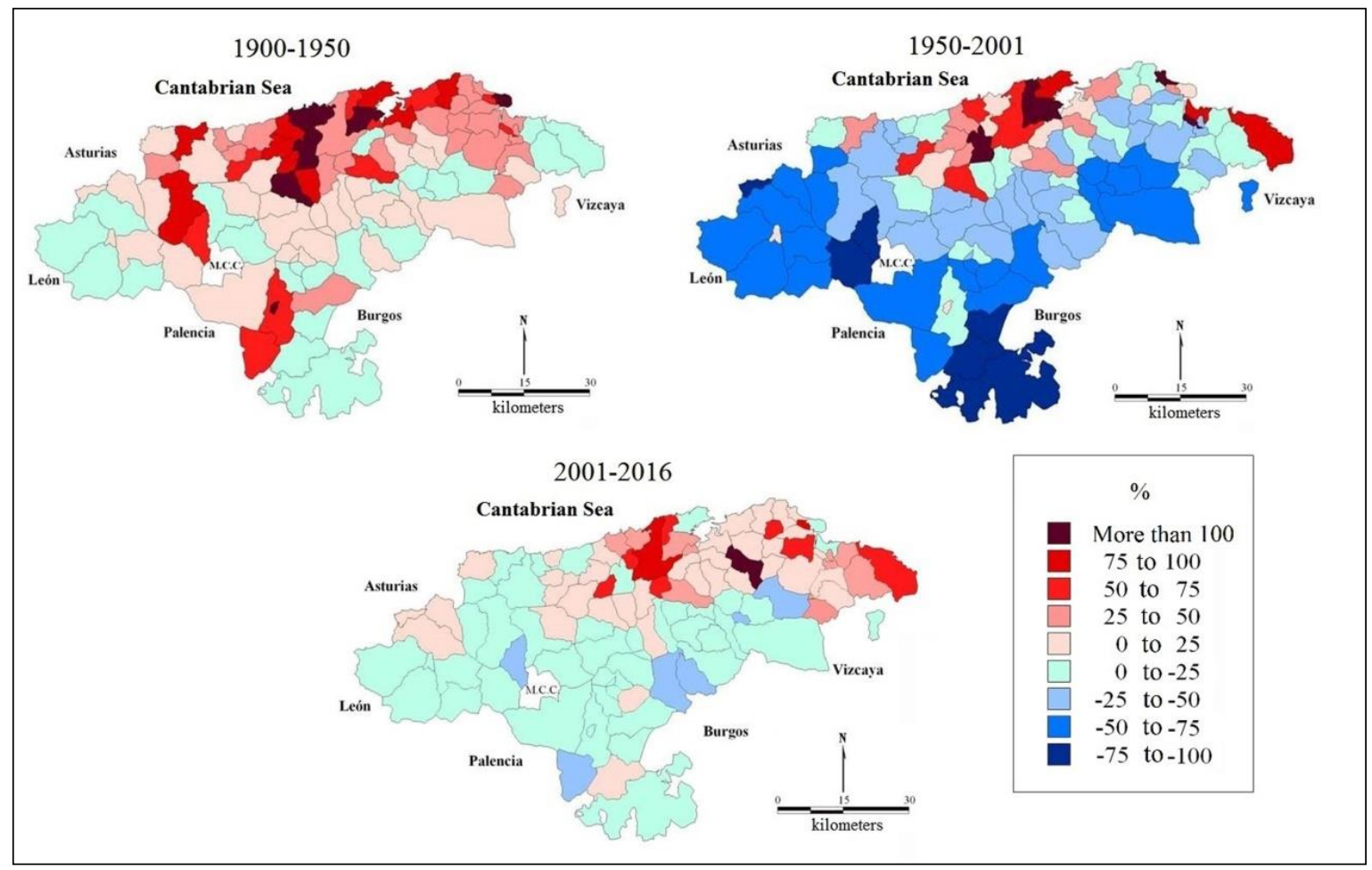

Fig 6. Cantabrian population dynamics from 1900 to 2016. Source: by the author based on INE data, population censuses and municipal residents' registers.

A severe territorial imbalance in population distribution emerged over the course of the $20^{\text {th }}$ century in Cantabria. Over those 100 years, Cantabria's population increased by $93.9 \%$, but this growth only affected the northern central region between the urban areas of Santander and Torrelavega, a space occupied by urban, suburban and peri-urban municipalities where populations at least doubled. To these, it must be added some others located on the west coast, and above all, the east coast between the mouth of the River Asón and Castro Urdiales. In the rest of the region, however, 60 rural municipalities mainly located in inland mountain areas 
experienced varying, but always significant, degrees of population loss. Only municipalities that functioned as regional capitals escaped this process of depopulation in mountain districts, instead experiencing significant population growth, which has probably contributed to securing their function as secondary urban centres in their respective rural areas.

The greatest spatial contrasts between urban and rural areas occurred during the period of industrial expansion, which was when the largest population losses were recorded. Between 1950 and 1970, the population in Cantabria increased modestly (15.37\%); however, 74 out of 102 municipalities (72.5\%) witnessed population losses, many of them which were very significant. At first, the process of what could rightly be described as depopulation mainly affected mountain areas in the south-western and central sector of Cantabria. Only those municipalities located close to the urban centres of Santander, Torrelavega, Santoña, Laredo and Castro Urdiales experienced significant growth. Not only did an accelerated process of depopulation in rural mountain areas continue until the end of the $20^{\text {th }}$ century, but it became even more intense and extended to the rest of the mountain areas.

The result for the second half of the $20^{\text {th }}$ century was bleak. While the regional population grew by $32.16 \%$ between 1950 and 2001, 71 municipalities experienced population decline: 27 of them lost over $50 \%$ of the population they had in 1950 and 6 of these lost more than $75 \%$ of their inhabitants.

With antecedents in the 1990s, the early $21^{\text {st }}$ century has witnessed different demographic trends. In particular, the marked contrasts between districts in the previous stage have lessened somewhat, since the gains and losses have in both cases been moderate. Another novel phenomenon is the emergence of negative values for population trends in urban areas, since with the exception of Castro Urdiales, the population has declined in all urban centres (Santander, Torrelavega, Laredo, Santoña, Reinosa). This is because it is only now that the new population dynamics are becoming evident, associated with dispersed housing developments that are supplanting the model of concentrated development typical of industrialised societies. Thus, there has been a gradual modification of trends towards centralisation, which seems to reflect a shift towards a more diffuse territorial model as a partial result of peri-urbanisation and metropolisation.

This explains why the number of registered residents in municipalities in Cantabria increased by $10.38 \%$ between 1996 and 2016, however, this growth has occurred mainly in the peri-urban areas of Torrelavega and Santander, and along the far eastern coast around Castro Urdiales, which to some extent has begun to function as a peri-metropolitan area of Bilbao. Disturbingly, even in this new scenario of moderate population growth and dispersion, the same rural areas are continuing to experience a decline in population. This is not very encouraging as regards the effectiveness of the rural development programmes implemented in these areas during this period.

The demographic characteristics of the rural population in Cantabria are a consequence of the briefly outlined population trends throughout the 20th century, and especially in the second half, when a rapid rural exodus constituted a genuine population outflow. Of greater concern is the fact that this has continued, albeit more slowly, in the early 21 st century.

This rural exodus began early, before the mid-20th century, in some districts, but reached a peak in the 1960s and continued throughout subsequent decades. Between 1970 and 1991, rural municipalities in Cantabria lost 23,485 inhabitants, a little over a fifth of the population in 1970 (- $0.9 \%$ a year), whereas the region as a whole gained 63,143 inhabitants, $13.5 \%$ ( $0.6 \%$ per year). In the 1990s, the process of population redistribution slowed down: in rural municipalities, the population continued to decline at a slower rate $(-0.5 \%$ per year) while the population of the region as a whole continued to increase modestly ( $0.1 \%$ per year) (Table 2$)$.

The new century has brought with it a new population dynamic, with widespread growth. However, the values for this increase vary widely across the region: whereas rural areas gained fewer than 4,000 people (4.67\%) between 2001 and 2008, which was the last year of the general growth cycle, the region as a whole gained 44,532 inhabitants $(8.28 \%)$. This minimal recovery is entirely insufficient as it barely offsets previous losses, not even those that took place in the previous decade alone. In summary, one could argue that in the last third of the 20th century and the early 
21 st century, the rural exodus has continued, albeit more slowly and with rates which are gradually diminishing.

Tab 2. Recent trends in the rural population of Cantabria between 1970 and 2016. Source: by the author based on INE data, population censuses and municipal residents' registers.

\begin{tabular}{|l|c|c|c|c|c|c|c|c|c|c|}
\hline Period & \multicolumn{2}{|c|}{$\Delta 1970-1991$} & \multicolumn{2}{c|}{$\Delta 1991-2001$} & \multicolumn{2}{c|}{$\Delta 2001-2008$} & \multicolumn{2}{c|}{$\Delta 2008-2016$} & \multicolumn{2}{|c|}{$\Delta$ 1996-2016 } \\
\hline Area & People & $\%$ & People & $\%$ & People & $\%$ & People & $\%$ & People & $\%$ \\
\hline $\begin{array}{l}\text { Rural } \\
\text { municipalities }\end{array}$ & $-23,485^{\star}$ & -20.29 & $-4,519^{\star}$ & -4.90 & $4,126^{\star}$ & 4.67 & $-1,984^{* *}$ & -2.42 & $-2,873^{\star *}$ & -3.47 \\
\hline Total Cantabria & 63,143 & 13.52 & 4,850 & 0.91 & 44,532 & 8.28 & 68 & 0.01 & 54,769 & 10.38 \\
\hline
\end{tabular}

* In 2008, 71 municipalities were defined as rural; ** In 2016, only 67 municipalities were still defined as rural

The demographic trend briefly described here is not only different over time, but also spatially, since not all rural municipalities have been affected in the same way.

Between 1970 and 1991, the population declined throughout all southern mountain districts, especially in municipalities in the upper Nansa River region and the southern valleys of Campoo, which lost more than half their population in just 21 years. Losses were relatively moderate in the district of Liébana, although they affected all municipalities except Potes, in Campoo and in areas in the upper Miera and Asón river valleys.

Even though the rate of population decline fell more smoothly between 1991 and 2001, the process continued in most rural municipalities, although there was an encouraging recovery, at least in relative terms, in some municipalities in Liébana, Cabuérniga and Campoo. However, this did not compensate for previous losses.

In brief, demographic trends between 1970 and 2001 clearly illustrate the imbalances between rural areas. With the partial exception of regional capitals and their neighbouring communities, municipalities in mountain districts witnessed a substantial decline in their populations. In the nine that lost over $50 \%$ of their inhabitants in those thirty years, it is no exaggeration to speak of a genuine process of depopulation. In contrast, municipalities located in the middle and lower valleys or close to urban areas experienced much smaller population losses and some even gained inhabitants.

Disturbingly, the early $21^{\text {st }}$ century has witnessed a continuation of the rural exodus within a broader context of widespread growth and often population recovery in some rural areas.

From 2001 to 2008, when the recovery cycle started, rural Cantabria experienced a slight increase in population, but this was very uneven and merely served to heighten the contrasts between different types of rural area. With very few exceptions, the rural municipalities that have witnessed population gains have been located in the vicinity of urban areas in the north of Cantabria and even more so in the eastern coastal area (the Marina Oriental), which in most cases are undergoing intensive processes of functional transformation. These changes are so profound that four municipal districts located on the eastern coast of the region (Bárcena de Cicero, Castañeda, Entrambasaguas and Meruelo) have lost their status as rural areas in terms of exceeding the density threshold of population, 100 inhab. $/ \mathrm{km}^{2}$, between 2008 and 2016 . Here, a large number of second and holiday homes have been built for an urban population that often lives in the metropolitan area of Bilbao. In contrast, most municipalities in southern mountain districts have continued to witness population losses, sometimes in substantial relative proportions.

The impact on population trends of the economic crisis that has beset Spain since 2008 has been particularly severe in rural areas in Cantabria. While the regional population in Cantabria has remained stagnant between 2008 and $2016(0.01 \%)$, the population of rural spaces has continued to decrease $(-2.42 \%)$. 


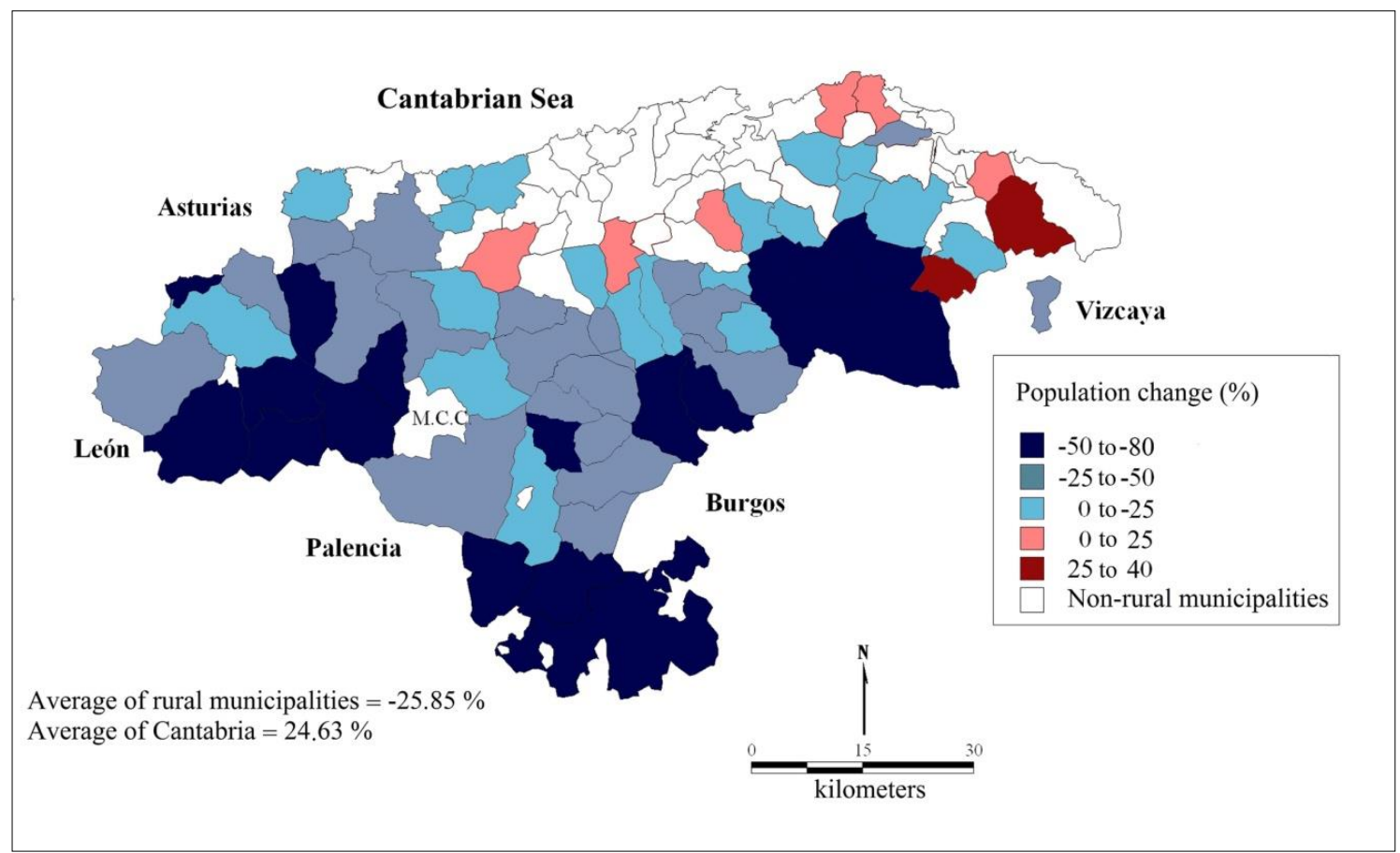

Fig 7. Recent dynamics of the rural population in Cantabria from 1970 to 2016. Source: by the author based on INE data, population censuses and municipal residents' registers.

Thus, in the twenty years between 1996 and 2016, while the whole Cantabrian population grew by $10.4 \%$, the rural municipalities continued having significant losses $(-3.47 \%$ between 1996 and 2016), although most have once again lost up to a quarter of the population they still had and sixteen of them have lost between $25 \%$ and $50 \%$.

The overall balance of the last forty-five years is bleak: practically, all rural municipalities in mountain districts have witnessed massive population losses: the total population of Cantabria has increased by $24.63 \%$ between 1970 and 2016 at the same time that the population of rural municipalities decreased by $25.85 \%$ (Fig. 7 ).

The process of depopulation has been less severe in municipalities located along the transition to the urban and peri-urban coast in the north. Only those located closest to the coast in the eastern half of the region and in the metropolitan area of Santander-Torrelavega have remained immune. On the contrary, many rural municipalities, in particular, those in southern mountain districts, are becoming truly depopulated.

The most worrying aspect is that even in this new scenario of population dispersion, the same rural areas are continuing to witness population losses. This is the case in most of Liébana, now including its capital, Potes; the Saja-Nansa river valleys; almost all of Campoo, including Reinosa; the Pas and Miera river valleys, even in Selaya; and in the Asón River valley. This is not very encouraging as regards the effectiveness of the rural development programmes implemented in these areas during this period. Only municipalities that have functioned as regional capitals seem to have escaped this process of depopulation in mountain districts, instead experiencing significant population growth, which has probably contributed to securing their function as secondary urban centres in their respective rural areas.

Recent population losses are due to two different but complementary factors: a negative natural increase beginning in the last quarter of the twentieth century and a very small positive migratory balance, even during the period when immigration had a significant influence on population growth in many parts of the Spanish and Cantabrian territory.

Regarding the first factor, according to the data provided by the National Institute of Statistics, the net natural movement of the whole of the Cantabrian population was negative between 1996 and $2016,-14,856$ people. Of this total figure, $-10,113(68.07 \%)$ correspond to the 67 rural 
municipalities whose population at the time represented no more than $13.7 \%$ of the regional population.

As regards the migratory balance, rural municipalities only received about $4,300(13.8 \%)$ of the 31,097 people who immigrated to Cantabria between 2005 and 2016, with similar absolute values of internal and external migratory balance (Fig. 8).

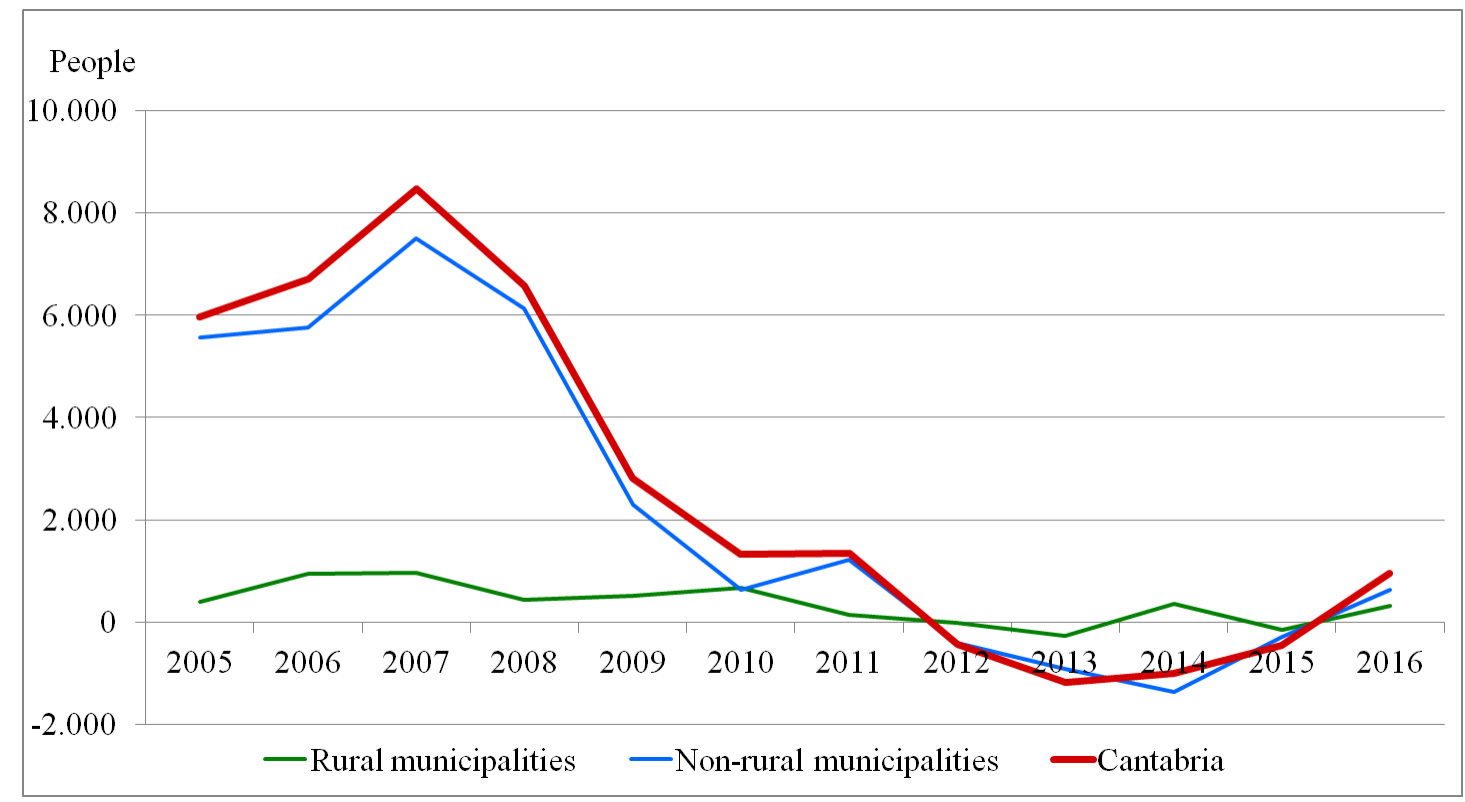

Fig 8. Migratory balance of Cantabria (2005-2016). Source: by the author based on INE data, Natural Movement of Population

\subsection{A very low population density}

According to data collected by the INE from municipal residents' registers, the mean population density in Cantabria in 2016 was 109.30 inhabitants $/ \mathrm{km}^{2}$, slightly higher than the Spanish mean (92 inhab. $/ \mathrm{km}^{2}$ ), whereas in municipalities classified as rural, mean density was only 26.66 inhabitants per $\mathrm{km}^{2}$. Furthermore, these averages mask an even bleaker reality because the disparities are still greater at municipal level.

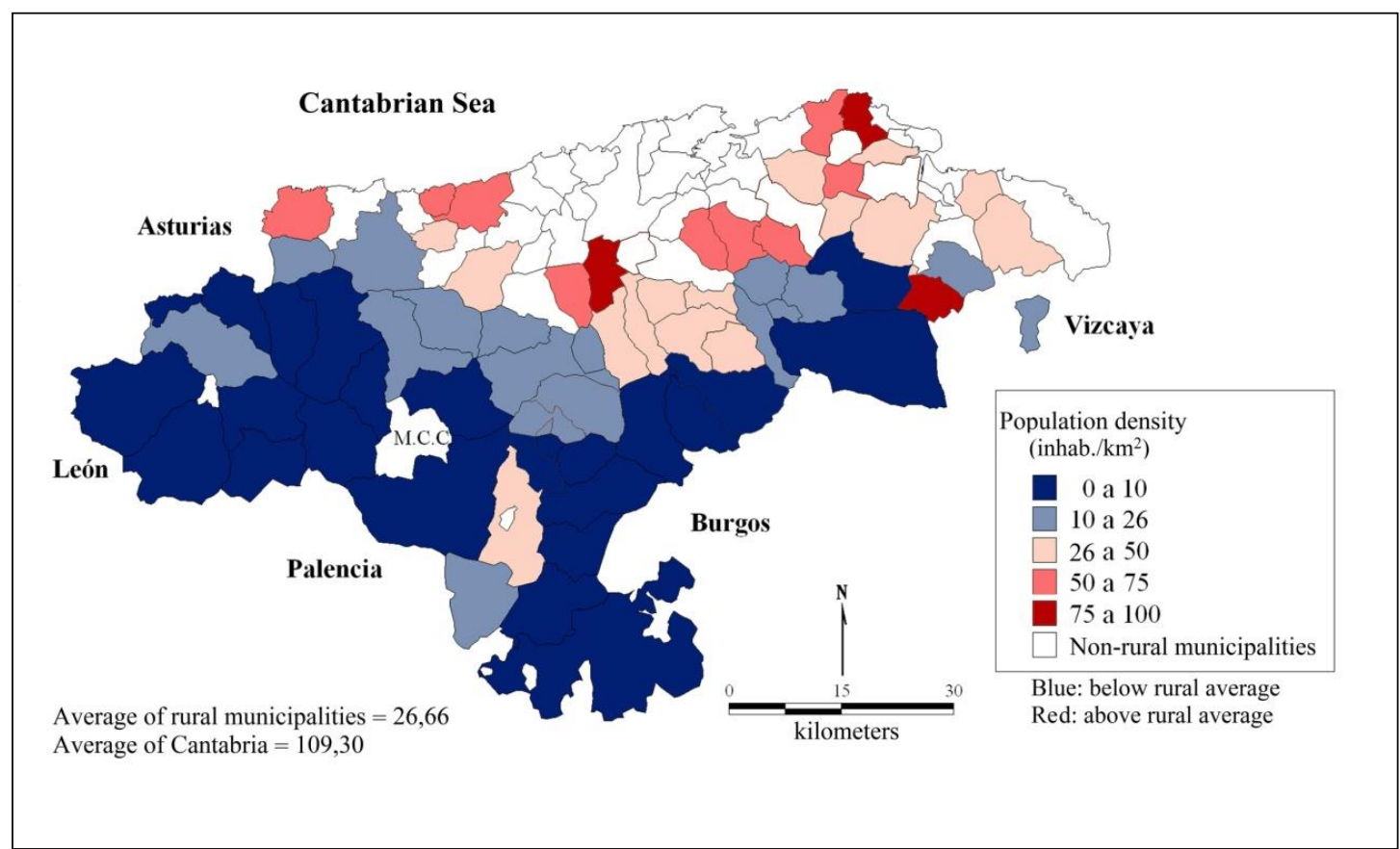

Fig 9. Population density of the Cantabrian rural areas (2016). Source: by the author based on INE data, population censuses and municipal residents' registers 
The municipalities beyond the urban and peri-urban areas have population densities below 100 inhabitants $/ \mathrm{km}^{2}$, although with significant differences between them. Some of the rural municipalities closest to or even sandwiched between the former, have mean densities of between 50 and 100 inhabitants $/ \mathrm{km}^{2}$. However, the vast majority of rural municipalities have below 25 inhabitants $/ \mathrm{km}^{2}$, and a significant number of them (24) fall below 10 inhabitants $/ \mathrm{km}^{2}$. As it can be seen (Fig. 9), these municipalities are located in the southwestern quadrant of the region, and in general, throughout the southern mountain area. Population densities are particularly low in practically all municipalities in Liébana; the middle and upper valleys of the Saja and Nansa rivers; Campoo; and the upper Pas, Miera and Asón river valleys. Together, these districts form a mountain ring of depopulation in Cantabria ${ }^{11}$.

The situation is aggravated by the fact that most rural settlements in Cantabria are dispersed. Dispersion levels calculated from municipal residents' register data for 2016 present very high values: mean dispersion in Cantabria as a whole is $17.8 \%$, whereas $62.0 \%$ of the population in rural municipalities live in small population entities other than the main urban centre or in isolated houses, a proportion that rises to more than three quarters in many municipalities.

In fact, only two rural municipalities present lower dispersion levels than the mean: Tresviso, which only has one centre of population and thus lacks a dispersed population, and Ramales de la Victoria, whose population mainly resides in the municipal capital. The other municipalities present very high indices of dispersion.

Although the pattern of dispersion is not clearly defined, the highest rates correspond to mountain areas in the west (Liébana and Cabuérniga-Tudanca), centre (Campoo) and east (Soba). Furthermore, the levels of rural population dispersion are considerably higher than those provided by the statistical data, which do not compute absolute dispersion because isolated houses are classified as belonging to a centre of population that in reality does not exist but is simply a specific territory.

\subsection{An ageing and masculinised population with little ability to recover}

As a whole, the population in Cantabria is in an advanced process of ageing; in 2016, the regional mean percentage of people aged over 65 years old was $20.67 \%$ of the total population, more than 8 percentage points above what is considered the ageing threshold value.

Although there is no precise ageing pattern distribution, in general, the rates are inversely proportional to the size of the municipalities, with the highest rates corresponding to the smallest ones and the lowest to the largest. Predictably, this confirms the correlation between degree of population ageing and population trends. Municipalities located in southern mountain districts, and especially in the western and central quadrants, present the highest rates, often above $30 \%$.

Conversely, only a small number of municipalities, almost all located in the north and near urban areas, present indices of ageing that are close to, although almost always above, the regional mean. It is only in some peri-urban municipalities that the rates are quite low, sometimes even lower than the threshold of $12 \%$ (e.g., $10.3 \%$ in Cartes, located in the peri-urban area of Torrelavega) or very slightly above it (e.g., $12.3 \%$ in Piélagos, and $12.9 \%$ in Entrambasaguas, in the peri-urban area of Santander, or $12.5 \%$ in Meruelo, on the eastern coast).

Evidently, present-day conditions are very different depending on whether the area is urban, periurban and rural, as are the future prospects of each in light of these results (Fig. 10).

One of the most harmful consequences of the depopulation that has occurred in recent decades is that the areas with the lowest levels of human occupation are also those with the highest rate of ageing, which reaches very high values in these places. In a large number of rural municipalities, the percentage of people aged over 65 years old exceeds the mean value for rural areas in Cantabria (27.72\%). Municipalities in the southern mountain districts, and especially in the western (Liébana and Tudanca) and central (Campoo) quadrants, present the highest rates.

\footnotetext{
11 The municipalities with the lowest densities in 2016 were Polaciones $\left(2.6\right.$ inhab/km $\left.{ }^{2}\right)$ and Tudanca $\left(2.8 \mathrm{inhab} / \mathrm{km}^{2}\right)$ in the county of Tudanca; Valderredible $\left(3.4 \mathrm{inhab} / \mathrm{km}^{2}\right)$ and Valdeprado del Río $\left(3.7\right.$ inhab/ $\left./ \mathrm{km}^{2}\right)$ in the county of Campoo.
} 
For example, $36.60 \%$ of the population in Santiurde de Reinosa (Campoo) is aged over 65 years old; $37.54 \%$ in Peñarrubia; $41.61 \%$ in Lamasón (Cabuérniga-Tudanca); and $35.03 \%$ in Vega de Liébana.

Other indicators of the demographic structure complement the previous image. Thus, the youth rate, the percentage of children under 15 years of age, already low in Can-tabria $(13.57 \%)$, is much lower in rural municipalities where the average is $9.35 \%$. But in addition, it should be noted that only twelve of them are close to the regional average while the majority are far below, reaching negligible values in some of those located in the western mountainous regions (Tudanca, 1.36\%, Tresviso, 2.82\%, Lamasón, 3.69\%) and centrals (Pesquera, $4.23 \%$, Santiurde de Reinosa, $4.91 \%)$.

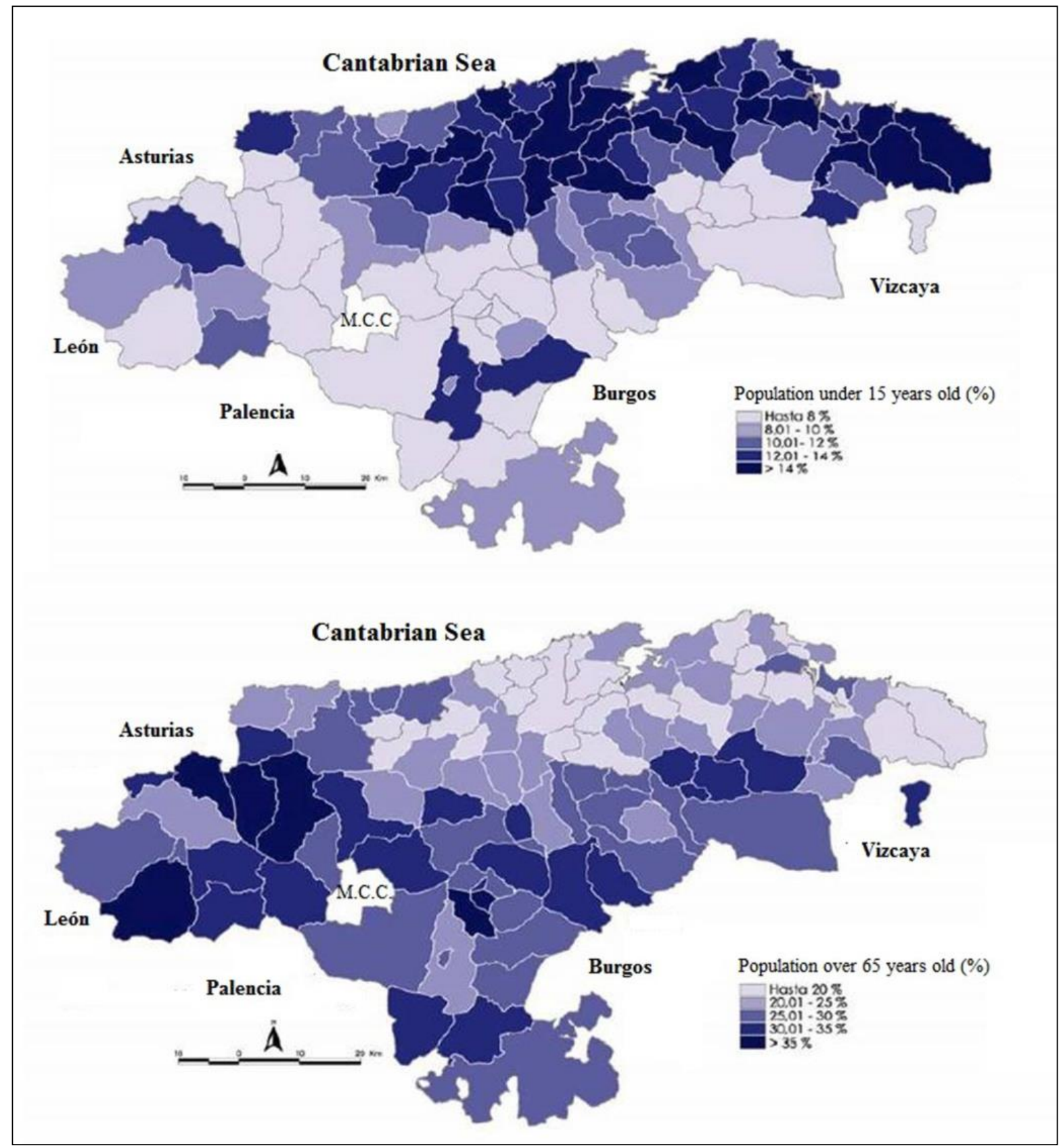

Fig 10. Ageing and youth rates of Cantabrian population (2016). Source: remodeled by the author based on Statistical Institute of Cantabria (ICANE)

The masculinity rate (number of males per 100 people) also provides a significant picture of the demographic structure of rural Cantabrian spaces. As it corresponds to an aging population, the regional average rate is $48.61 \%$ in 2016 while in the set of rural municipalities, it rises to 
$53.88 \%$, with only five of them below $50 \%$ and many more (18) above $55 \%$, reaching extreme values in some of the previously mentioned: Pesquera, $60.56 \%$, Lamasón, $63.42 \%$, Polaciones, $63.71 \%$, Tresviso, $67.61 \%$ and Tudanca, $72.11 \%$.

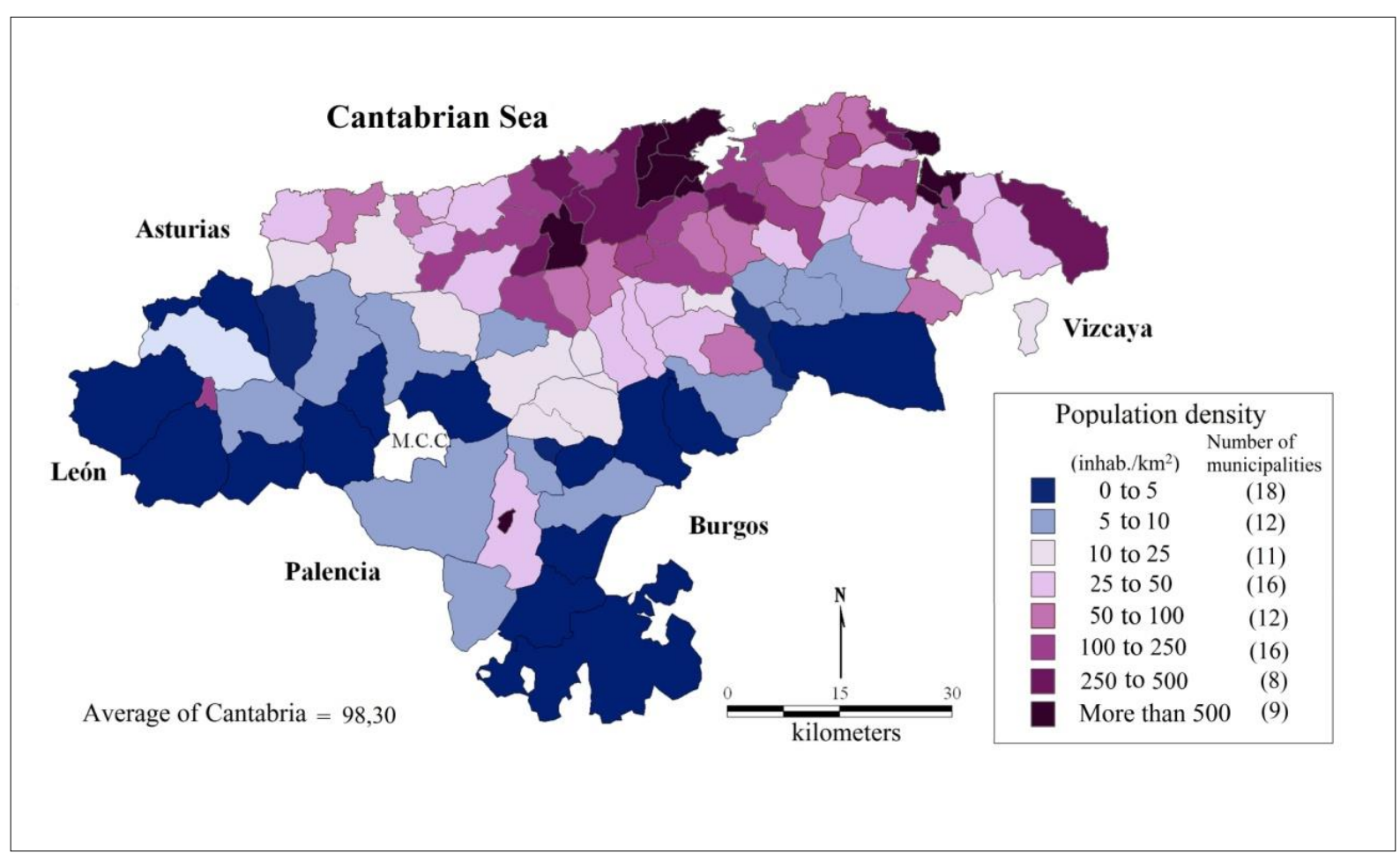

Fig 11. Population density of the Cantabrian municipalities (data projection for the year 2037). Source: by the author based on Statistical Institute of Cantabria (ICANE)

Considering the above data, those relating to the natural movement of the population are not surprising. Regional average rates of birth and death in 2016 were $10.2 \%$ and $7.3 \%$ respectively, resulting in a natural increase of $-2.9 \%$. Corresponding to 67 rural municipalities, the numbers are significantly lower in the case of the birth rate, $5.8 \%$, and higher with regard to the mortality rate, $13.9 \%$, being $-8.1 \%$ a natural balance. This is compounded by the fact that only five municipalities have had a slightly positive balance and three others have matched births and deaths. Most of the other 59 rural municipalities have reached negative values beyond $-10.0 \%$.

The current situation predicts a future with a very serious population loss, even depopulation (Fig. 11). Thus, the Statistics Institute of Cantabria (ICANE) has calculated that between 2017 and 2037 , the region as a whole will lose $9.25 \%$ of its population: $8.58 \%$ from non-rural municipalities and $13.5 \%$ from rural municipalities. According to this projection, mean regional density will drop to 98.3 inhab. $/ \mathrm{km}^{2}$ and 25.43 inhab. $/ \mathrm{km}^{2}$ in rural areas: 30 municipalities will not reach the threshold of 10 inhab. $/ \mathrm{km}^{2}, 18$ will have fewer than 5 inhab. $/ \mathrm{km}^{2}$ and another 5 will not reach 3 inhab. $/ \mathrm{km}^{2}$. Extreme cases such as Tudanca and Polaciones will only have 1.13 inhab. $/ \mathrm{km}^{2}$ and 1.84 inhab. $/ \mathrm{km}^{2}$, respectively, transforming them into demographic deserts.

\subsection{The diminished relative importance of agriculture among the active population}

In the past, primary sector activities were very important in Cantabria, but their importance has steadily declined in both absolute and relative terms, until reaching the current situation in which only 6,828 people are registered as working in fisheries and agriculture, from a total of 203,643 active residents, accounting for $3.35 \%$ of the population according to data provided by the National Institute of Social Security and Statistical Institute of Cantabria (ICANE) for 2016. In contrast, the other sectors of activity have gained importance.

In 2016 , a total of 14,107 (6.92\%) people were employed in construction, an especially important activity in some rural areas close to peri-urban and coastal areas where residential construction 
has become extremely important over the last decade. Here, work in construction has compensated for the loss of agricultural jobs.

Industry employs 30,015 (14.73\%) people, a very small number compared with the impact it had in previous decades. In addition, industrial activity has a very precise spatial distribution, with higher concentrations in municipalities on the central coast, around Santander and Torrelavega, on the eastern coast, on the outskirts of the Ría de Treto and Castro Urdiales and along the Besaya corridor. With these exceptions, there is very little industrial activity in most rural areas of Cantabria, especially in the mountain districts of Liébana, Cabuérniga-Tudanca and Pas. Consequently, industrial employment does not replace or complement agricultural employment.

In contrast, most of the active population is employed in service activities, which provided work for 152,694 (74.98\%) people registered with Social Security in 2016 . The available data reveal a marked shift towards the service economy in Cantabria's active population that has affected both urban and rural areas, although not in the same way. Rates of tertiary sector employment are highest in the urban agglomeration in the northern central area of the region, between Santander and Torrelavega, and along the eastern end of the coast, around Laredo and Castro Urdiales.

In general, there is less service economy employment in inland rural municipalities, except in those that are regional capitals offering services, such as Potes in Liébana and Ramales de la Victoria in the Asón valley. There is also much more tertiary employment in some places in Liébana and Cabuérniga, where rural tourism is more strongly developed.

Agriculture is no longer the rural occupation par excellence; however, it continues to be important in most Cantabrian rural municipalities (Fig. 12). The Social Security data for residents in each municipality show that a relatively high percentage of people in rural municipalities $(20.65 \%)$ are employed in agriculture, but this figure masks very different situations, ranging from less than $5 \%$ in some municipalities on the eastern coast (Liendo, Voto, Castañeda) to more than $50 \%$ in others in the Montes de Pas (Vega de Pas, San Pedro del Romeral).

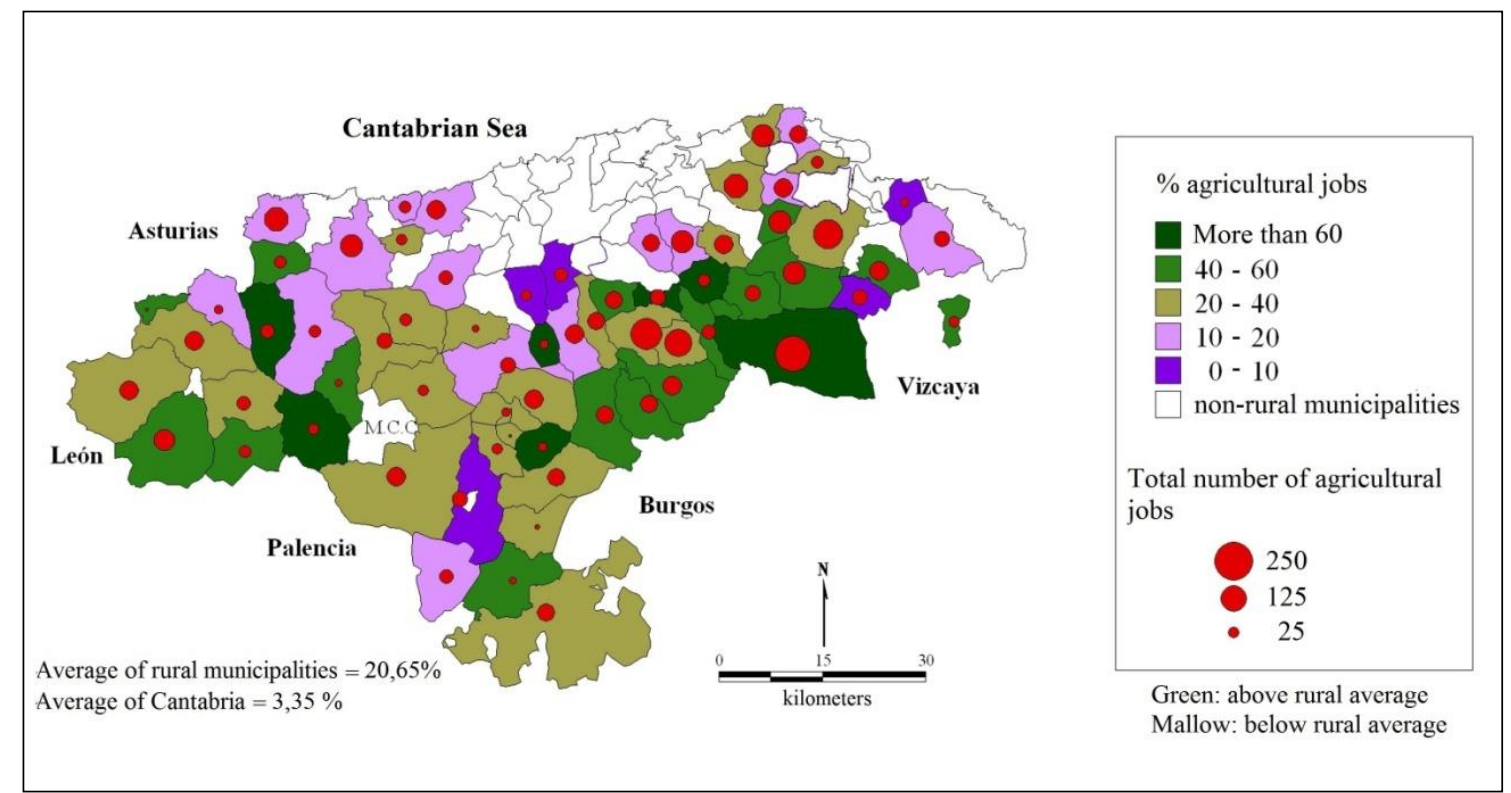

Fig 12. Distribution of the Cantabrian rural population employed in agriculture (2016). Source: by the author based on National Institute of Social Security (INSS) data

As with the other aspects analyzed, there is a very strong correlation between the proportion of agricultural jobs and the size of municipal populations. The values are very high for municipalities with 100 to 500 inhabitants, where, in general, nearly half of the active population works in agriculture. In those with 500 to 1,000 inhabitants, the percentage is almost $40 \%$, whereas in preurban municipalities with 1,000 to 2,000 inhabitants, it falls below $30 \%$. In general terms, 
employment rates in agriculture are highest in the western (Liébana and Cabuérniga-Tudanca) and eastern central (the upper Pas, Miera and Asón river valleys) mountain districts.

The territorial distribution is even more revealing. Southern mountain municipalities can be considered the last stronghold of agricultural activity since in most cases more than a quarter, and often more than half, of their active population are employed in this sector. Most of the 13 municipalities with more than $30 \%$ of their active population employed in agriculture are located in the mountain area of Liébana, the eastern mountain range and the upper Pas, Miera and Asón river valleys, unquestionably constituting the last bastion of agricultural activity.

Nevertheless, there are few jobs in agriculture in each of the rural municipalities, in part because of their small populations and in part due to the recent decline in this activity. In 31 municipalities $(46.26 \%)$, there are fewer than 50 jobs in agriculture, and only 7 municipalities $(10.44 \%)$ have more than 100 people employed in agriculture.

\subsection{Lower income among inhabitants of rural areas}

Gross disposable income per capita is an indicator that synthesises the imbalances observed in the unequal distribution of the other indicators analyzed so far. Together, these clearly highlight the disadvantages affecting most rural areas, particularly those with the fewest inhabitants, with the partial exception of those located in urban and peri-urban areas.

According to data from the Cantabrian Institute of Statistics, the mean gross disposable income per capita in the region in 2015 was $€ 14,190$, but there were marked differences between areas.

Once again, a directly proportional relationship can be observed between this indicator and number of inhabitants: the lowest incomes correspond to rural municipalities with fewer inhabitants, whereas the highest correspond to the most populated semi-urban and urban municipalities.

From a spatial perspective, the distribution repeats the pattern observed for other indicators: the highest incomes are found in urban areas in the north-eastern half of the region, where the major regional cities and their peri-urban municipalities are located, whereas the lowest incomes are found in small rural municipalities in southern mountain districts (Fig. 13).

Once again, a directly proportional relationship can be observed between this indicator and number of inhabitants: the lowest incomes correspond to rural municipalities with fewer inhabitants, whereas the highest correspond to the most populated semi-urban and urban municipalities.

The income of the inhabitants of almost all the 67 rural municipalities is below the regional average, with a mean value of $€ 10,059$. Only a few rural-urban municipalities, mostly located in the eastern coastal area, present a higher per capita income than the regional average. The lowest figures correspond to three rural mountain municipalities (San Roque de Riomiera, Polaciones and Tresviso), all with a mean per capita income of below $€ 6,000$. In this respect, the territorial distribution of income clearly shows a very defined pattern: the lowest mean incomes correspond to mountain areas in the western and eastern quadrants of the region, while the highest, in relative terms, correspond to rural municipalities located on the northern coast, particularly in the eastern zone, and those along the Besaya corridor, in the districts de Iguña and Campoo. 


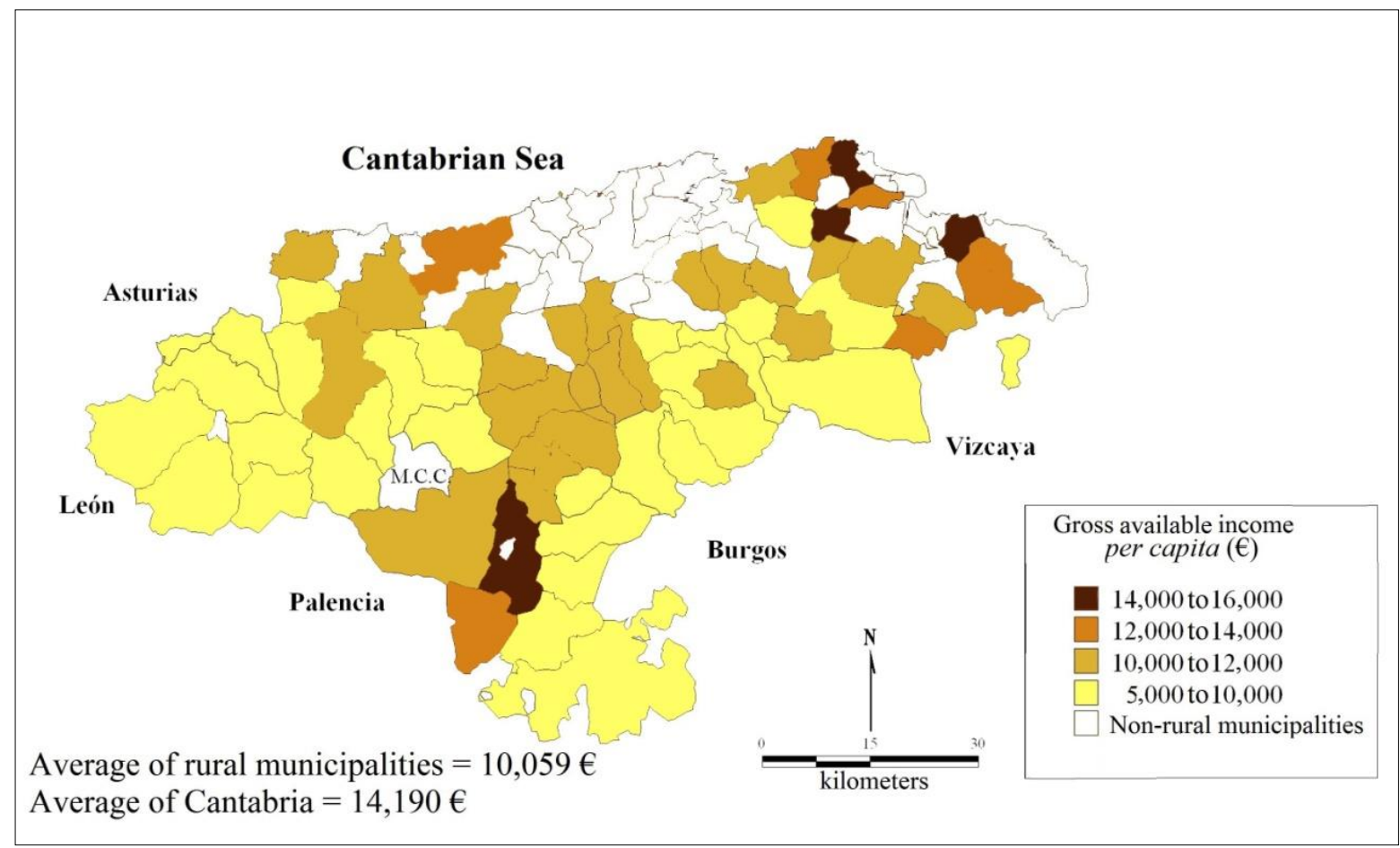

Fig 13. Distribution of per capita gross available income in the Cantabrian rural municipalities (2015). Source: by the author based on Statistical Institute of Cantabria (ICANE) data

\section{Conclusions}

The most striking result of this combined analysis of the selected indicators is the marked duality presented by rural areas in Cantabria, a situation that is echoed in rural areas in other Spanish regions. In this case, the greatest contrasts correspond to those between the rural and peri-urban coastal areas and mountainous rural areas that are very distant or less accessible from urban spaces.

Very pronounced and revealing inequalities are evident in different population dynamics and their effects, the absolute volume and density of the population, demographic characteristics, the biological structure of the rural population and the ability to recover.

The situation of the territorial area comprising the mountainous municipalities is extremely brittle. Having witnessed substantial population loss, the population volume is very low, despite making up the greater part of the territory of Cantabria. This is clearly illustrated by mean population density values: in the northern area closest to the coast, the mean number of inhabitants per square kilometre is close to 78, whereas the same figure in southern rural areas is less than 9, far below the established minimum standards of between 25 and 30 inhab. $/ \mathrm{km}^{2}$ needed to ensure potential demographic recovery.

Furthermore, in a context of very high values, the rate of old age is significantly higher in municipalities in the southern mountainous area (30.86\%) than in the northern coastal region (19.33\%). Thus, the Cantabrian mountain areas are at real risk of depopulation.

Identical contrasts are evident in the occupational structure of the population. In the coastal zone, agricultural jobs account for only slightly more than $11 \%$, whereas in the mountainous area, these provide almost $38 \%$ of total employment, despite the lack of economic diversification and an advanced process of deagrarianisation.

It is therefore not surprising that there are notable inequalities in mean gross disposable income per capita; whereas inhabitants of the coastal peri-urban zone have a theoretical mean income of around $€ 11,000$, in the mountainous area, this figure barely exceeds $€ 8,000$.

The rate of dispersion and distance in time to urban centres with more services in the region are also indicators that reflect the comparative disadvantage of municipalities in mountain areas 
regarding deficiencies in physical accessibility, facilities and basic services.

These socioeconomic disadvantages clearly explain the current problematic situation of mountain areas in Cantabria and, by extrapolation, of Spain as a whole and even of the European Union.

In these cases, depopulation has not occurred as a recent single event, as is sometimes depicted in the media. On the contrary, it has been the result of a lengthy process which will be difficult to reverse, and whose solution, if any exists, requires strong political will. There is an urgent need to move from words to action and implement public policies at state, regional, local and other levels, in a joint effort involving the public authorities and civil society.

The need to stabilise the current population and also attract new residents demands the implementation of initiatives to improve the provision of basic quality services in the fields of education, health and dependence; to boost physical and online accessibility in all territories by providing appropriate infrastructures; to stimulate economic diversification in order to generate new jobs suited to the needs of the new rural population; and even to implement fiscal actions to ameliorate the situation of particularly disadvantaged rural areas through positive tax discrimination as a territorial investment.

It should be noted that the process of depopulation analyzed here reveals a significant deficit in territorial cohesion that has wrought serious damage on mountain areas, true "loser areas" and victims of a genuine territorial crisis that includes and is evident in a demographic problem and territorial imbalance that has generated a process of population redistribution initiated a century ago.

Consequently, it is necessary to implement innovative and integrated actions in Strategic Territorial Planning that encompass multiple and diverse measures and sectoral initiatives in order to advance towards the sustainable development of mountain rural spaces.

\section{Acknowledgments}

This research was funded through the project Cultural Landscapes in the World Heritage List. Keys and criteria for the identification and management of agricultural, mining and industrial landscapes of northern Spain [Paisajes culturales de la Lista Patrimonio Mundial. Claves para la identificación y criterios para la gestión de paisajes agroganaderos, mineros e industriales de la España Atlántica]. Funding body: Secretary of State for Research Directorate General for Research and Management of the National R\&D\&i Plan, Subdirectorate General for Research Projects, National R\&D\&i Plan 2016-2019, non-oriented Basic Research Projects, Coordinated Projects CSO2015-65787-C6-3-P.

Academic references

[1] Alario Trigueros, M., Molinero Hernando, F. \& Morales Prieto, E. (2018). La persistencia de la dualidad rural y el valor de la nueva ruralidad en Castilla y León (España). Investigaciones Geográficas, 70, 9-30. DOI: 10.14198/ingeo2018.70.01.

[2] Albera, D. \& Corti, P., eds. (2000). La montagna mediterranea: una fabbrica d'uomini?Mobilità e migrazioni in una prospettiva comparata (secoli $X V-X X$ ), Cavallermaggiore: Gribaudo.

[3] Aparicio Guerrero, A. E. \& García Marchante, J. S. (2016). La despoblación del medio rural en Castilla-La Mancha: Estado de la cuestión y propuestas de dinamización socioeconómica. In Ruiz Pulpón, A. R., Serrano de la Cruz Santos-Olmo, M. A. \& Plaza Tabasco, J., eds., Treinta años de Política Agraria Común en España: Agricultura y multifuncionalidad en el contexto de la nueva ruralidad (pp. 457-472). Ciudad Real: AGE.

[4] Ayuda Bosque, Mª. I., Pinilla Navarro, V. \& Sáez Pérez, L. A. (2000). El problema de la despoblación en Aragón causas, características y perspectivas. Revista de Demografía Histórica 18(1), 137-173. 
[5] Ayuda, M. I. \& Pinilla, V. (2002). El proceso de desertización demográfica de la montaña pirenaica en el largo plazo: Aragón. Ager. Journal of Depopulation and Rural Development Studies 2(2), 101-138.

[6] Ayuda Bosque, Ma . I., Collantes Gutiérrez, F. \& Pinilla Navarro, V. (2010). Long-run Regional Population Divergence and Modern Economic Growth in Europe: a Case Study of Spain. The Annals of Regional Science 44(2), 273-295. DOI: 10.1007/s00168-008-0260-9.

[7] Ballas, D., Kalogeresis,T. \& Labrianidis, L. (2003). A comparative study of typologies for rural areas in Europe. In ERSA Conference Papers (ersa 03p515). Regional Science Association.

[8] Bauer, G. \& Roux, J. M. (1976). La rurbanisation ou la ville èparpille. Paris: Seuil.

[9] Berdegué, J. A. \& Proctor, F. J. (2014). Cities in the Rural Transformation [Working Paper Series Nr. 122]. Santiago de Chile: Centro Latinoamericano para el Desarrollo Rural.

[10] Berry, B. (1976). Urbanization and counterurbanization. Beverly Hills: Sage Publications.

[11] Bibby, P. \& Shepherd, J. (2004). Developing a new classification of urban and rural areas for policy purposes. The methodology. London: Department for Environment, Food and Rural Affairs.

[12] Bustos Alecha, H. (2016). Desarrollo rural en áreas de montaña: el Pirineo Navarro. $M+A$. Revista Electrónic@ de Medio Ambiente, 17(2), 1-19. DOI: 10.5209/MARE.54798.

[13] Bustos Gisbert, M $M^{a}$ L. (2018). Evolución de la población rural en la provincia de Salamanca (2000-2014). Boletín de la Asociación de Geógrafos Españoles, 77, 200-228.

[14] Camarero Bullón, L. (2009). La población rural de España. De los desequilibrios a la sostenibilidad social. Barcelona: Fundacion La Caixa.

[15] Camarero Rioja, L. (2002). Pautas y tendencias demográficas del medio rural: la población rural en la última década del siglo XX. In Gómez, C. \& González, J. J., eds., Agricultura y Sociedad en el Cambio de Siglo (pp. 63-78). Madrid: McGraw Hill.

[16] Camarero Rioja, L., ed. (2009). The rural population in Spain. From disequilibrium to social sustainability. Barcelona, Fundación La Caixa.

[17] Carrasco Lera, A. (2012). Despoblación y repoblación rural. Reflexiones y experiencias. Ambienta: La revista del Ministerio de Medio Ambiente 99, 48-62.

[18] Castro, J. \& Belo, M. (1992). Quelle perspective pour les agricultures dans les zones de montagne du Portugal?. Revue de Géographie Alpine 4, 117-127.

[19] Cloke, P. J. (1977). An index of rurality for England and Wales. Regional Studies 11(1), 143 152. DOI: $10.1080 / 09595237700185041$.

[20] Cloke, P. (2006). Conceptualizing rurality. In Cloke, P., Marsden, T. \&y Mooney, P., eds., Handbook of rural studies (p. 18), London: Sage.

[21] Coleman, D. \& Rowthorn, R. (2011). Who's Afraid of Population Decline? A Critical Examination of Its Consequences. Population and Development Review, 37, 217-248.

[22] Collantes Gutiérrez, F. (2001b). La montaña española en el desarrollo capitalista, 18601991: perifericación segura, difusión condicionada. Ager: Revista de estudios sobre despoblación y desarrollo, 1, 9-45.

[23] Collantes Gutiérrez, F. (2004a). El declive demográfico de la montaña española (1850 2000). ¿Un drama rural? [Serie Estudios, $n^{\circ}$ 159]. Madrid, Ministerio de Agricultura, Pesca y Alimentación.

[24] Collantes Gutiérrez, F. (2004b). Convergencia económica "por defecto" en el medio rural español: El caso de las zonas de montaña, 1970-2000. Revista Asturiana de Economía, 29, 135-155.

[25] Collantes Gutiérrez, F. (2005). Declive demográfico y cambio económico en las áreas de montaña españolas, 1860-2000. Revista de Historia Económica, 23(3), 515-540. 
[26] Collantes Gutiérrez, F. (2007a). La desagrarización de la sociedad rural española, 19501991. Historia agraria: Revista de agricultura e historia rural, 42, 251-276.

[27] Collantes Gutiérrez, F. (2007b). The decline of agrarian societies in the European countryside: a case study of Spain in the twentieth century. Agricultural History, 81(1), 7697.

[28] Collantes, F. \& Pinilla, V. (2004). Extreme Depopulation in the Spanish Rural Mountain Areas: a case study in Aragon in the 19th and 20th centuries. Rural History. Economy, Society, Culture 15(2), 149-166.

[29] Collantes Gutiérrez, F. \& Pinilla Navarro, V. (2011). Peaceful surrender: the depopulation of rural Spain in the twentieth century. Newcastle-upon-Tyne, Cambridge Scholars Publishing.

[30] Commins, P. (1978). Socio-economic adjustments to rural depopulation. Regional Studies, 12(1), 79-94. DOI: 10.1080/09595237800185071.

[31] Dadà, A. (2000). Uomini e strade dell'emigrazione dall'Appennino toscano. In Albera, D. \& Corti, P., eds., La Montagna Mediterranea (pp. 153-164). San Giovanni Lupatoto: Gribaudo.

[32] Delgado Urrecho, J. Ma \& Martínez Fernández, L. C. (2017). Envejecimiento y desequilibrios poblacionales en las regiones españolas con desafíos demográficos, Ería, 1 (nueva época), 21-43. DOI: 10.17811/er.1.2017.21-43.

[33] Delgado Viñas, C, ed. (2006). La Montaña Cantábrica, una montaña viva. Santander: Servicio de Publicaciones de la Universidad de Cantabria/Parlamento de Cantabria.

[34] Delgado Viñas, C. (2007). Breve historia crítica y análisis comparativo de las políticas aplicadas en Europa a la áreas de montaña, Investigaciones geográficas 42, 35-59. DOI: 10.14198/INGEO2007.42.02.

[35] Delgado Viñas, C. (2008). Las áreas de montaña en Cantabria ante el reto de su desarrollo sostenible. Polígonos. Revista de Geografía 18, 93-122. DOI: 10.18002/pol.v0i18.200.

[36] Delgado Viñas, C. (2013). Population dynamics of Spanish mountain areas: case study of two regions in the Cantabrian Mountains (Spain). Journal of Settlements and Spatial Planning. 2, 207-217.

[37] Delgado Viñas, C. (2018). El estado actual del proceso de despoblación de los espacios rurales de Cantabria. In Cejudo García, E., Navarro Valverde, F. A. \& Camacho Ballesta, J. A., eds., Nuevas realidades rurales en tiempos de crisis: territorios, actores, procesos y políticas (pp. 147-162). Granada: Universidad de Granada.

[38] Desbordes, F. \& Laborie, J. P. (1991). L'évolution récente de la population dans les Pyrénées françaises. Revue Géographique des Pyrénées et du Sud-Ouest 62(1), 7-18.

[39] Díez, Ch. (2019). (Des)población. Cuaderno de campo 62, 4-2.

[40] Domínguez Álvarez, J. L. (2019). La despoblación en Castilla y León: políticas públicas innovadoras que garanticen el futuro de la juventud en el medio rural. Cuadernos de Investigación en Juventud, 6. DOI: 10.22400/cij.6.e028.

[41] Dubois, A. \& Roto, J. (2012). Making the best of Europe's Sparsely Populated Areas, Stockholm: NORDREGIO.

[42] Dunaway, W. A. (1996). The Incorporation of Mountain Ecosystems into the Capitalist WorldSystem. Review 19(4), 355-381.

[43] Entrena Durán, F. (2005). El fenómeno de la periurbanización en Europa. Granada: Universidad de Granada.

[44] Entrena Durán, F. (2006). Rururbanización y transformaciones en los usos y significados de los espacios rurales. In Alonso Benito, L. E. et al., eds., El cambio social en España (pp. 145-160). Sevilla: Centro de Estudios Andaluces. 
[45] Entrena Durán, F. (2012). La ruralidad en España: de la mitificación conservadora al neorruralismo. Cuadernos de desarrollo rural, 69(9), 39-65.

[46] Estienne, P. (1989). Évolution de la population des montagnes françaises au XXe siècle. Revue de Géographie Alpine 77(4), 395-406.

[47] García Sanz, B. (2003). ¿Se acabó el éxodo rural? Nuevas dinámicas demográficas del mundo rural español. In García Pascual, F., ed., La lucha contra la despoblación todavía necesaria: políticas y estrategias sobre la despoblación en las áreas rurales del siglo XXI (pp. 13-42). CEDDAR: Zaragoza.

[48] Giusti, U. (1943). Le dépeuplement des régions montagneuses en Italie. Bulletin Mensuelde Renseignements Économiques et Sociaux 34(9), 295-322.

[49] Goerlich, F. J., Reig, E. \& Cantarino, I. (2016). Delimitación y caracterización de las áreas rurales españolas [Working Papers]. University of Valladolid.

[50] Gómez-Limón Rodríguez, J. A., Atanque Muñiz, I. \& Rico González, M. (2007). Percepción pública del problema de la despoblación del medio rural en Castilla y León. Ager: Revista de estudios sobre despoblación y desarrollo rural 6, 9-60.

[51] Gómez Mendoza, J. (2016). Actualidad territorial de las montañas. Distintas miradas, nuevas políticas. In Vera Rebollo, J. R., Olcina Cantos, J., Hernández Hernández, M. \& Morals Gil, A., eds., Paisaje, cultura territorial y vivencia de la geografía (pp. 143-166). University of Alicante.

[52] Guirado González, C. \& Tulla i Pujol, A. (2010). Entre l'abandonament i l'ús intensiu del territori? Sistema d'assentaments i gestió del territori en espais de muntanya. El cas de l'Alt Pirineu Català. Documents d'anàlisi geogràfica, 56(3), 607-623.

[53] Herbin, J. \& Remmer, J. (1984). L'évolution démographique des Alpes austro-allemandes. Revue de Géographie Alpine 72(1), 21-40.

[54] Hoggart, K., Buller, H. \& Black, R. (1995). Rural Europe. Identity and Change. London: Arnold.

[55] Hoggart, K. \& Paniagua, A. (2001a). What rural restructuring? Journal of Rural Studies 17, 63-80. DOI: 10.1016/S0743-0167(00)00036-X.

[56] Hoggart, K. \& Paniagua, A. (2001b). Rural restructuring in Spain? Journal of Rural Studies 17, 63-80. DOI: 10.1016/S0743-0167(00)00037-1.

[57] Johnson, K. M. \& Lichter, D. T. (2019). Rural Depopulation: Growth and Decline Processes over Century the Past. Rural Sociology, 84(1), 3-27. DOI: 10.1111/ruso.12266.

[58] Jornad, F., Lambotte, M., Ramos, F., Terres, J. M. \& Bamps, C. (2009). Delimitations of rural areas in Europe using criteria of population density, remoteness and land cover. Luxembourg: Office for Official Publications of the European Communities.

[59] Lawton, R. (1973). Rural depopulation in nineteenth century England. In Mills, D. R., ed., English rural communities. The impact of a specialised economy (pp. 195-219). London: Macmillan.

[60] Leco Berrocal, F., Pérez Díaz, A. \& Mateos Rodríguez, A. B. (2016). Población y poblamiento en la Extremadura rural: desequilibrios territoriales e incapacidad demográfica. In Ruiz Pulpón, A. R., Serrano de la Cruz Santos-Olmo, M. A., Plaza Tabasco, J. Treinta años de Política Agraria Común en España: Agricultura y multifuncionalidad en el contexto de la nueva ruralidad (pp. 741-751). Ciudad Real: AGE.

[61] Leco, F., Pérez, A. \& Mateos, A. B. (2017). Crisis demográfica en la Extremadura rural: valoración a través de los Grupos de Acción Local (2007-2014). Cuadernos Geográficos, 56(1), 76-100.

[62] López Fernández, B. (2016). Poblamiento y declive demografico en Asturias, 2000-2014. Ería, 99-100, 95-108. 
[63] López Trigal, L. (2009). Despoblación y reconfiguración territorial en España. In López Trigal, L., Abellán, A. \& Godenau, D., eds., Despoblación, envejecimiento y territorio: un análisis sobre la población española (pp. 529-546). León: Universidad de León.

[64] Macarrón Larumbe, A. (2011). El suicidio demográfico de España. Madrid: Homolegens.

[65] MacDonald, D., Crabtree, J. R., Wiesinger, G., Dax, T., Stamou, N., Fleury, P., Gutierrez Laspita, J. \& Gibon, A. (2000). Agricultural abandonment in mountain areas of Europe: Environmental consequences and policy response. Journal of Environmental Management, 59(1), 47-69. DOI: 10.1006/jema.1999.0335.

[66] Matanle, P. \& Rausch, A. S. (2011). Japan's shrinking regions in the $21^{\text {st }}$ century. London: Cambria Press.

[67] Mathieu, J. (2000). Storia delle Alpi 1500-1900. Ambiente, sviluppo e società. Bellinzona: Casagrande.

[68] Mazzoleni, M. \& Negri, G. G. (1981). La situación de la montaña en Italia. Ciudad y Territorio 1, 25-37.

[69] Merlin, P. (1965). La dépopulation des plateaux de la moyenne Durance (Valensole, Forcalquier, Saint-Christol): La part respective du mouvement naturel et de l'émigraion. Annales de géographie 74(404), 432-446.

[70] Miranda Barros, D., Crecente Masade, R. \& Álvarez Taboada, Ma F. (2006). Land consolidation in inland rural Galicia, N.W. Spain, since 1950: An example of the formulation and use of questions, criteria and indicators for evaluation of rural development policies. Land Use Policy 23(4), 511-520. DOI: 10.1016/j.landusepol.2005.05.003.

[71] Molino Molina, S. del (2016). La España Vacía. Madrid: Turner Publicaciones.

[72] Negri, G. G. (1993). Les montagnes de Lombardie. Revue de Géographie Alpine 2, 65-83.

[73] Palacios, A., Pinilla Navarro, V. \& Sáez Pérez, L. A. (2017). La despoblación en Aragón, 2000-2016: tendencias, datos y reflexiones para el diseño de políticas [Working paper]. Universidad de Zaragoza.

[74] Pasakarnis, G. Morley, D. \& Maliene, V. (2013). Rural development and challenges establishing sustainable land use in Eastern European countries. Land Use Policy 30(1), 703-710. DOI: 10.1016/j.landusepol.2012.05.011.

[75] Pazo Labrador, A. J. \& Moragón Arias, Ma P. (2018). El despoblamiento en Galicia: la visualización de la "catástrofe". Ager: Revista de estudios sobre despoblación y desarrollo rural 24, 123-154.

[76] Pérez Díaz, A. \& Leco Berrocal, F. (2018). La despoblación rural en Extremadura. In Cejudo García, E., Navarro Valverde, F. A. \& Camacho Ballesta, J. A., eds., Nuevas realidades rurales en tiempos de crisis: territorios, actores, procesos y políticas (pp. 248-260). Universidad de Granada.

[77] Pinilla, V., Ayuda, $M^{a}$ I. \& Sáez, L. A. (2006). Rural depopulation in mediterranean western Europe: a case study of Aragon [Working paper]. University of Zaragoza.

[78] Pinilla Navarro, V. \& Sáez Pérez, L. A. (2017). Rural depopulation in Spain: genesis of a problem and innovative policies. Zaragoza: CEDDAR.

[79] Pires de Almeida, M. A. (2017). Territorial inequalities: depopulation and local development policies in the Portuguese rural world. Ager. Revista de Estudios sobre Despoblación y Desarrollo Rural 22, 61-87.

[80] Pokos, N., Turk, I. \& Živić, D. (2015). Depopulation and population ageing of rural areas in Bjelovar-Bilogora County (1961-2011). Dela, 43, 123-140. DOI: 10.4312/dela.43.8.123140.

[81] Ratier, H. E. (2002). Rural, ruralidad, nueva ruralidad y contraurbanización. Un estado de la Cuestión. Revista de Ciencias Humanas 31, 9-29. 
[82] Rauch, T. (2014). New ruralities in the context of global economic and environmental change -are small-scale farmers bound to disappear? Geographica Helvetica, 69(4), 227-237.

[83] Rieutort, L. (1997). Les moyennes montagnes d'Europe occidentale: affaiblissement ou réadaptation des campagnes?. Norois 173, 61-83.

[84] Rieutort, L. (2012). Du rural aux nouvelles ruralités. Revue Internationale d'Education de Sèvres 59, 43-52. DOI :10.4000/ries.2267.

[85] Rodríguez Pastor, J. (2017). La Siberia extremeña (1927-2017). Revista de estudios extremeños 73( 2), 1775-1812.

[86] Santos González, J. \& Redondo Vega, J. Ma (2016). Gestión, protección y despoblación en las Reservas de la Biosfera de la Cordillera Cantábrica. Pirineos, 171, 25. DOI: 10.3989/Pirineos.2016.171009.

[87] Saville, J. (1957). Rural Depopulation in England and Wales, 1851-1951. London: Routledge.

[88] Smailes, P. J., Argent, N. \& Griffin, T. L. C. (2002). Rural population density: its impact on social demographic aspects of rural communities. Journal of Rural Studies 18(4), 385-404. DOI: 10.1016/S0743-0167(02)00033-5.

[89] Short, B. (2000). Rural demography, 1850-1914. In Collins, E. J. T., ed., The agrarian history of England and Wales VII: 1850-1914 (pp. 1.232-1.296). New York and Cambridge: Cambridge University Press.

[90] Sorokin, P. \& Zimmerman, C. (1929). Principles of rural-urban sociology. New York: Henry Holt.

[91] Thorez, P. \& Reparaz, A. de (1987). La population et le peuplement dans le Caucase oriental et dans les Alpes du Sud. Formes traditionnelles, formes contemporaines, différenciations régionales. Méditerranée 61(2-3), 95-110.

[92] Vartiainen, P. (1989). The end of drastic depopulation in rural Finland: Evidence of counterurbanisation? Journal of Rural Studies 5(2), 123-136. DOI: 10.1016/07430167(89)90041-7.

[93] Woods, M. (2005). Rural geography: Processes, responses and experiences in rural restructuring. London: Sage.

[94] Wrigley, E. A. (2001). Country and town: the primary, secondary, and tertiary peopling of England in the early modern period. In Slack, P., ed., The peopling of Britain (pp. 217-242). Oxford, Oxford University Press.

[95] Wuthnow, R. (2018). The Left Behind: Decline and Rage in Rural America. Princeton, NJ: Princeton University Press.

[96] Xingan, Li (2015). Rural Depopulation in China: A Comparative Perspective. Revista Internacional y Multidisciplinar en Ciencias Sociales, 4(2), 149-174.

Other sources

[97] ADE (2012). Study on the relevance and the effectiveness of ERDF and Cohesion Fund support to Regions with Specific Geographical Features - Islands, Mountainous and Sparsely Populated areas, pp. 10-13.

[98] Delgado Viñas, C. (2009). Estudio de base para la delimitación de las zonas de aplicación en Cantabria de la Ley de Desarrollo Sostenible del Medio Rural. Gobierno de Cantabria. Consejería de Desarrollo Rural, Ganadería, Pesca y Biodiversidad. Santander (Informe inédito). 
[99] European Commission (1988). The future of the rural world. Communication from the European Commission to the Council and the European Parliament of July 29, 1988, COM (88) 501. Bulletin of the European Community, supplement $n^{\circ} 4 / 88$. Luxembourg. Office of the Official Publications of the European Union.

[100] Eurostat (2010). A revised urban-rural typology. Eurostat Statistical Books, KS-HA-10001.

[101] Federación Española de Municipios y Provincias (FEMP) (2017a). Listado de medidas para luchar contra la despoblación en España.

[102] Federación Española de Municipios y Provincias (FEMP) (2017b). Población y despoblación en España 2016. Madrid, 11 pp.

[103] Gáková, Z. \& Dijkstra, L. (2010). Does population decline lead to economic decline in EU rural regions? Regional Focus.

[104] García Valdivia, A. (2018). The Challenge Of Rural Depopulation: Facing The Scenario Of Demographic Deserts In The EU. Forbes, 22 Dec 2018. https://www.forbes.com/sites/anagarciavaldivia/2018/12/22/the-challenge-of-ruraldepopulation-facing-the-scenario-of-demographic-deserts-in-the-eu/\#40299fed1295.

[105] González Regidor, J., ed. (2008). Desarrollo rural sostenible: un nuevo desafío.LEY 45/2007, de 13 de diciembre, para el Desarrollo Sostenible del Medio Rural. BOE nº 299 de 14 de diciembre de 2007. Madrid, Ministerio de Medio Ambiente, Medio Rural y Marino/Mundi-Prensa.

[106] Margaras, V. (2016). Sparsely populated and underpopulated areas. European Parliament. http://www.europarl.europa.eu/RegData/etudes/BRIE/2016/586632/EPRS_BRI(2016)586 632_EN.pdf.

[107] Münz, R. (2006). Europe: Population and Migration in 2005. Migration Information Source. Brussel: Migration Policy Institute.

[108] Nikitina, S. V. (2000). Population Decline and Population Ageing in the Russian Federation. Presented to the Expert Group Meeting on Policy Responses to Population Ageing and Population Decline, Population Division of the Department of Economic and Social Affairs, U.N. Secretariat, New York, New York, October , pp. 16-18.

[109] OECD (1994). Creating rural indicators for shaping territorial policy. Paris: OCDE. OECD (2010). Regional Typology. Paris. http://www.oecd.org/cfe/regional-policy/48670214.pdf.

[110] OECD (2006). El nuevo paradigma rural. Políticas y gobernanza. Madrid: Ministerio de Agricultura, Pesca y Alimentación.

[111] Senado de España (2015, 17 de abril). Comisión Especial de Estudio para la adopción de medidas en relación con la despoblación rural en España [...]. Boletín Oficial Cortes Generales España, 505. http://www. senado.es/legis10/publicaciones/pdf/senado/bocg/BOCG_D_10_505_3392.PDF.

[112] Waldorf, B. (2006). A continuous multi-dimensional measure of rurality: moving beyond threshold measures. The American Agricultural Economics Association Annual Meeting. Long Island, California, July 24-27. https://www.pcrd.purdue.edu/files/media/MeasuringRurality.pdf. 